Founders and Financially Affiliated Directors on Charter School Boards and Their Impact on Financial Performance and Academic Achievement

Charisse A. Gulosino ${ }^{\text {a, * }}$

Elif Şişli-Ciamarra ${ }^{\mathrm{b}}$

${ }^{\text {a }}$ Teachers College, Columbia University

${ }^{\mathrm{b}}$ International Business School, Brandeis University

${ }^{*}$ Corresponding author. Department of Education Policy \& Social Analysis, Teachers College, Columbia University, New York, NY, 10027, United States.

Tel: + 1646251 8134; fax 12126783036 .

Email address: cag2022@columbia.edu (C. Gulosino). 


\title{
Founders and Financially Affiliated Directors on Charter School Boards and Their Impact on Financial Performance and Academic Achievement
}

\begin{abstract}
This study uses a hand-collected dataset for charter school boards in Massachusetts between 2001 and 2009 to examine the relationship between financial performance and the presence of founders and financially affiliated directors. School-level financial performance suggests that founder presence on a board has a negative effect on both financial and academic performance of a charter school. On the other hand, the presence of financially affiliated directors on the charter school governing board is positively related to financial performance, but unrelated to academic achievement. The results are consistent with the literature on corporate and nonprofit boards that have attributed financially affiliated directors with greater incentives to monitor financial targets, while founders are less likely to achieve performance expectations.
\end{abstract}

JEL classification: H75, I20, L29

Keywords: Charter schools, Board governance, Financial performance, Achievement

Acknowledgements

We would like to thank the Massachusetts Department of Elementary and Secondary Education Charter School Office, as well as Cliff Chuang, Lee DeLorenzo, and charter school principals and administrators in Massachusetts for making this project possible. We appreciate the helpful comments from Wayne Jones and Howard Nelson, and anonymous reviewers for this Journal. We thank Deniz Civril for her very capable research assistance. We have benefited from comments from seminar and conference participants at Brown University (25 October 2011), the American Education Finance Association (11 April 2008, Denver CO), the American Educational Research Association (9 April 2007, Chicago, IL; 14 April 2012, Vancouver Canada), the National Charter School Conference (21 June 2011, Atlanta GA), the National Education Finance Conference (3 May 2012, San Antonio, TX), and the International Symposium on the Economics of Education (18 December 2011, Hong Kong). 


\section{Introduction}

Charter schools are publicly funded yet privately managed schools that operate in five year incremental contracts and are subject to renewal under a performance contract primarily based on fiscal solvency and student achievement (Bulkley, 2001; Bulkley \& Wohlstetter, 2003). They are governed by a "Board of Trustees" or a "Board of Directors." The board is accountable for the financial wellbeing of a charter school by approving capital assets, an operating budget, and closely monitoring its ability to remain fiscally solvent during the entire length of the charter. Another key role of the board is to ensure that a charter school achieves year-to-year improvement in academic performance. As charter schools face higher standards for accountability, performance, and competition for limited resources, greater attention has been given to the monitoring and oversight functions of charter school governing boards (Smith \& Wohlstetter 2006).

In this study, we explore the relationship between the presence of founders and financially affiliated boards of directors and the financial performance of charter schools using a unique, handcollected dataset of individual director and board characteristics for 60 charter schools in Massachusetts between 2001 and 2009. We focus on financial performance because charter school revocation/nonrenewal decisions - a rate of approximately 14 percent since 1992 (CER, 2008, 2009) - are most often due to financial mismanagement and governance problems, not educational issues (Finnigan et al, 2004).

Massachusetts is an excellent case study for several reasons. First, from their inception in 1994, charter schools in Massachusetts have been required to file annual reports as well as audited and unaudited financial statements, which we use to collect data on financial performance. Second, unlike other states, Massachusetts law does not mandate that charter school boards follow specific requirements on who can and cannot serve (Massachusetts Department of Elementary and Secondary 
Education, 2007, 2010). Third, the law explicitly allows charter school boards to be involved in cross-sectoral alliances as a way to enhance their financial capacity and improve educational services (National Alliance for Public Charter Schools, 2011).

Like their corporate and nonprofit counterparts, charter school board members are selected for their experience and expertise, as well as for their diverse backgrounds (Fama and Jensen, 1983). Charter school boards are predominantly comprised of teachers, parents, school administrators, community leaders and residents, and business executives who are initially recruited by school founders based on their willingness to provide resources, expertise, time and connections that are beneficial to the school. In this study, we focus on the presence of charter school directors that provide financial and material resources to the school: financially affiliated directors and founderdirectors. We define financially affiliated directors as board members with direct ties to nonprofit and corporate sponsors/contributors by serving as staff members, executives, or on boards of directors (Zimmer, Krop \& Brewer, 2003). On the other hand, founder-directors are board members responsible for securing basic financial and material needs during the pre-approval or preoperational stages of charter school development.

We posit that the participation of financially affiliated directors may improve the board's monitoring ability because, as active sponsors and contributors, they have the incentives and access to information and resources to carry out this function. In addition, representation of financially affiliated directors on the charter school governing board in a monitoring/oversight capacity may also minimize contracting costs (see Hansmann, 1988) insofar as they act as a credible signal to other donors that the academic program supplied by the charter school is of high quality and that financial resources are not being squandered (or captured) by school administrators and governing board. The literature on corporate and nonprofit boards suggests internal monitoring mechanism 
that may either complement the board's tasks of monitoring or incentivizing agent behavior (Fama \& Jensen, 1983) through independent internal control. Furthermore, we examine the differences between a non-profit and a for-profit organizational affiliation of financially affiliated directors as internal mechanism for monitoring charter school performance. An organizational affiliation is considered non-profit based on having a social mission or purpose to provide public support or charitable programs and services. By contrast, a for-profit affiliation is defined as a business or other organization whose main motives are profit generation and distributions of profit to stakeholders. We distinguish between a for-profit and a non-profit affiliation to determine whether such distinction appears to influence in one way or another the financially affiliated directors' contribution to charter school performance. For example, we investigate whether the overall impact of financially affiliated directors offers a stronger explanation than their organizational affiliation (i.e., for-profit or notprofit) for variations in both financial and academic outcomes.

Founders are another class of board members that possess strong financial and personal stakes in their organizations $(\mathrm{He}, 2008)$. Their involvement in the creation and management of an enterprise indicates stronger insider commitment and are less likely to be removed from the board, also known as entrenchment. Accordingly, Finkelstein \& Hambrick (1996) note that founderdirectors have the potential to configure boards and management that are less inclined to threaten their discretion, and they may compromise the best interests of the organization to serve their own interests, such as preserving their own positions and lowering their likelihood of departure (Zajac \& Westphal, 1996); Allgood \& Farrell, 2000; Duru et al., 2009). If there is a threshold point in the development of entrepreneurial organizations where information-processing/decision-making capabilities of founders are no longer sufficient to meet the organization's oversight needs as Gedajlovic et al. (2004) and Willard et al. (1992) discuss, then we would expect a negative 
relationship between the presence of founders and performance. Founders have been the research focus in a limited number of qualitative studies, most notably the negative effects of "Founder's Syndrome" or "founderitis" as described by the literature on both nonprofit and charter school boards (Linnell, 2004).

While the main focus of the study is on financial performance, we also analyze the nonfinancial aspect of school performance, namely, student achievement. The most efficient schools are ones that either use the fewest resources to produce a given level of student achievement or attain the most student achievement with a given level of resources (Levin \& McEwan, 2002; Levin \& Belfield, 2002). This argument is especially relevant in the charter school context since charter authorizers consider both financial viability and academic performance as criteria for approval in the chartering process and these dual objectives — academic achievement and financial targets — may compete or conflict.

In choosing our financial performance measure, we note that charter schools are similar to non-profit organizations in the sense that their objective is to achieve financial stability, rather than to maximize profits (i.e. Revenues - Expenditures). It is generally accepted that the charter school board has responsibility for reporting on the financial and operating results of the school on an annual basis. A charter school board needs to demonstrate the capacity for financial solvency and stability based on the financial plans and budgets it submits to the authorizer when applying for a charter, and then to work towards not falling short of budget projections and maintaining financial balance. Accordingly, we define our measure of financial performance as the difference between the estimated surplus and the actual surplus scaled by total assets of a charter school. Estimated surplus is the projected total revenues minus the projected total expenses for a given year. Actual surplus is the difference between total revenues and total expenses that are contained in audited annual 
financial statements. Almost all charter school board policies and procedures describe the basic responsibility of the board for reviewing financial statements, approving them, and then submitting them to charter school authorizers as part of the annual report filing. The financial performance measure we use serves as a proxy to assess the extent, if any, to which charter school exceeded, or fell short of its financial goals in a given year. Our financial performance measure incorporates two prime financial responsibilities of the charter school board, namely, to come up with a realizable school budget plan (estimated surplus) and to ensure that the school does not fall short of projections upon which the budget was based (actual surplus). This is an appropriate measure of financial performance that demonstrates a school's intent and commitment to stay fiscally healthy. It is also useful for supporting the notion that the board is responsible for creating an overall context of transparency and accountability.

The findings of this study make several contributions to the literature on charter schools. Previous studies on the organization, operation and governance of charter schools (Buddin and Zimmer, 2005; Hannaway and Sharkey, 2004; Bulkley, 2002; Miron and Nelson, 2002) focus on the type of school (profit, nonprofit, or public), and thus do not indicate which characteristics of charter school governing board are related to financial or academic performance. To the best of our knowledge this is the first study that investigates the composition of charter school boards, and the first attempt to empirically analyze the relationship between charter school financial performance and board composition. We find that charter school founders have a negative overall effect on financial performance and academic achievement. On the other hand, the presence of financially affiliated directors on charter school boards is related to higher financial performance and unrelated to academic achievement. The presence of financially affiliated directors who are also founderdirectors has a positive effect on both financial and academic performance. 
The findings on financially affiliated directors corroborate previous studies showing the importance of internal monitoring mechanism as an incentive to improve organizational performance (Jensen and Meckling, 1976; Fama, 1980; Fama \& Jensen, 1983). Our view of what the financially affiliated directors do complements the monitoring/oversight aspect prevalent in the literature on corporate and nonprofit board governance. As a monitor on behalf of organizations that provide financial and material support for charter schools, the presence of financially affiliated directors is found to have a positive impact on charter school performance. In this respect, board makeup becomes significant as the primary responsibility for ensuring organizational performance depends on members of the board that have particular incentives to exercise their monitoring function on behalf of sponsors and donors/contributors, whether for-profit or non-profit organizations. Studies that focus on a systematic relationship between board makeup and organizational performance are more widespread in the corporate governance literature than in the literature on nonprofit boards of directors (Daily et al., 1999; 2003). However, there is no well-developed board governance literature that considers the relationship between the various organizational types of financially-affiliated directors (for-profit or non-profit affiliations) and improved organizational performance (McClusky, 2002; Callen et al., 2003; Miller-Millesen, 2003).

In our empirical analysis we pay special attention to the possibility of self-selection of financially affiliated directors and founders onto charter school boards, because a comparison of charter school characteristics based on the presence or absence of both types of boards of directors reveals statistically significant differences. Therefore, we may identify differences in charter schools either because there is an effect of financially affiliated directors' presence on financial outcomes, or schools exhibit certain characteristics that make them more likely to have financially affiliated directors are also those more likely to achieve better financial performance. A similar analysis 
applies to founders. Thus, following corporate finance applications of self-selection (Li and Prabhala, 2007; Adams, Hermalin, and Weisbach, 2010; Şişli-Ciamarra, 2011), our empirical strategy adjusts for financially affiliated directors' and founders' self-selection into charter schools. We explicitly model director selection within an average treatment effects framework (Heckman, 1978). ${ }^{1}$ We detect if there is evidence of selection bias and, when appropriate, correct for it by estimating jointly the selection and structural outcome equation. In all specifications, we fail to reject self-selection.

The remainder of the paper is organized as follows. In the next section, we describe our data and variables. In Section 3 we explain our empirical strategy, and in Section 4 present our empirical results. Section 5 offers discussion and concluding remarks.

\section{Data and variables}

\subsection{Board variables}

In this study, we constructed a new dataset on board composition of charter schools in Massachusetts between 2001 and 2009. Our main source of information is the annual reports submitted to the Massachusetts Department of Education, Office of Charter Schools. The annual reports provide the names, titles/affiliations, biographies and tenure of members of charter school boards. In addition, we created a database of geographic distance for each director's workplace location and charter school location by calculating the straight-line distance between two points on a plane. $^{2}$

\subsection{Classification of board directors with financial interest by board type}

\footnotetext{
${ }^{1}$ Recent literature on the composition of corporate boards points out the importance of using the correct empirical methodology in the presence of self-selection (see Adams, Hermalin, and Weisbach, 2010).

${ }^{2}$ We use the straight line distance, or distance "as the crow flies," to compute distances between point pairs in ESRI ArcGIS software.
} 
We set a founder director variable in a given year equal to 1 for those individuals on the board who set up charter schools. To code founder-directors, we extracted records of all founders from charter school applications and renewal requests. We set a financially affiliated director variable in a given year equal to 1 to indicate on the school board those individuals with ties to cross-sectoral alliances that provide financial and material resources to charter schools. Building on prior description and analysis of the range of private givers to public education (Zimmer, Krop \& Brewer, 2003; Hansen, 2008), we define "financially affiliated directors" as board members with direct ties to locally based voluntary contributors, independent foundations and donors/sponsors by serving as a staff member, executive, or on a board of directors. To dummy code this variable, we conducted an exhaustive search for links between directors on a charter board and locally based voluntary contributors, independent foundations and corporate sponsors. First, we used the published charter school annual reports to create a complete list of board of directors and their institutional/professional affiliations and memberships, as well as the various sources of private support for charter schools. Second, we used online searchable directories of professional networks (i.e., Zoominfo, Linkedin) and archival sources (websites, newsletters, board minutes, local newspapers, company profiles and board listings) to create a detailed description of board member biographies/affiliations, locally based voluntary contributors, independent foundations, and sponsors of charter schools. Finally, to review and cross-reference our data set of locally based contributors, foundations, and corporate sponsors, we sent charter school administrators a one-question survey on external support.

As indicated earlier, charter school board members who are both financially affiliated directors and founder-directors are coded separately to distinguish the separate impact of the two types of boards of directors. 


\subsection{Classification of financially-affiliated directors by organizational type}

A non-profit organizational affiliation of financially affiliated director takes a value of one if the organization is considered a non-profit. It is organized for purposes other than generating profit and in which no part of the organization's funds or income stream is distributed to its members, directors, or officers. Non-profit organizations include social or community service organizations, independent foundations, and locally based voluntary contributors such as community foundations and charter school foundations.

A for-profit organizational affiliation of financially affiliated director takes a value of one if the organization's focus is to generate profits and maximize shareholder value. For-profit organizations include businesses from large financial institutions (i.e., Deutche Bank) to limited liability companies to professional corporations (i.e., law firms) to small business firms (i.e., entrepreneurs).

\subsection{Data on school finance}

The financial data for fiscal years 2001-2009 are obtained from annual reports and audited financial statements that charter schools submit to the state's Department of Education (DOE). Each financial data year contains a statement of revenues and expenditures, changes in net assets, and cash flows for the year ended; a balance sheet of the school's assets, liabilities, and fund balances or equities; and projections of income and expenses for the upcoming school year. The annual audited financial statements of charter schools obtained from DOE incorporate the actual year-to-date revenues and expenditures.

As discussed in the introduction, we define our measure of financial performance as the difference between the estimated surplus and the actual surplus scaled by total assets of a charter school. The financial performance measure we use serves as a proxy to determine the extent to 
which charter school exceeded, or fell short of its financial goals in a given year. Estimated surplus is defined as the projected total revenues minus the projected total expenses for a given year. This surplus estimate represents the net realizable value from the school's projected budget. Actual surplus is the difference between total revenues and total expenses that are contained in audited annual financial statements. This variable represents the net gain of the charter school board to avoid shortfalls or budget gaps. The difference between the estimated surplus and the actual surplus for each year of the budget window represents the intent to stay financially viable.

\subsection{Data on school characteristics and student achievement}

Data on school characteristics such as standardized achievement data (MCAS), teacher credentials, school enrollment, and student demographics are compiled using the Massachusetts Department of Education Report Cards for 2001-2009.

\subsection{Summary statistics}

Our final dataset consists of 485 charter school years of complete observations on board of directors, audited financial statements, teacher characteristics, and academic achievement variables.

In Tables 1, 2 and 3 we present summary statistics concerning select financial, academic, school and board characteristics. During our sample period, the average charter school board consists of 11.76 members (Table 1 Panel A). $75 \%$ of the schools have on average at least one founder serving on board. The average number of founders on a charter school's board is 1.96 with a standard deviation of 1.98 and a maximum of 12 founders. The mean board has 1.90 financially affiliated directors with a standard deviation of 1.99 and a maximum of 11 . This constitutes $70 \%$ of the boards on average with at least one financially affiliated director. 
In Table 1 Panel B we describe the evolution of charter school boards between 2001 and 2009. The average board size has remained unchanged from 2001 at 11.73 members to 2009 at 11.67 members. The average number of financially affiliated directors on a school's board decreased from 2.10 in 2001 to 1.47 in 2009 . However, the overall percentage of boards with at least one financially affiliated director remained constant over time at roughly $66 \%$. On the other hand, the representation of founders on the boards declined steeply from 2.83 in 2001 to 1.43 in 2009 , constituting 90 percent in 2001 and 64 percent in 2009 of boards with at least one charter school founder.

We define our measure of financial performance as the difference between the estimated surplus and the actual surplus scaled by total assets of a charter school, quantifying to what extent a charter school exceeded, or fell short of its financial goal in a given year. Panels A and B of Table 2 report no statistically significant differences in financial performance between the two means by board types. Before controlling for other differences in observable characteristics by board types, it appears that the presence of financially affiliated directors and founders on the board of directors has no impact on charter school financial performance.

We use school level average achievement scores as a proxy for academic performance. Prior research has guided the selection of mathematics test scores in this study (e.g., Carnoy \& Loeb, 2002). Beginning in 1998, the Massachusetts Comprehensive Assessment System (MCAS) was administered annually to eligible students enrolled in grades three through eight and in high school, including students with disabilities and those with limited English proficiency. Results of the MCAS mathematics assessment are reported for individual schools by four performance levels: advanced, proficient, needs improvement, and warning. We proxy academic performance using three measures: (i) Composite Performance Index (CPI), a state-generated measure of the extent to 
which students are progressing toward proficiency in mathematics; (ii) percentage of students who scored "Good" or higher in math (GHM); and (iii) math score index (MSI), a weighted average of performance at various levels of schools' overall scores. The CPI is a 100 point index obtained from MCAS scaled score results. We created new variables GHM and MSI to measure the aggregate school achievement score by averaging the scores from each performance level. The GHM is based on the weighted sum of school level achievement test scores at the advanced (4 points) and proficient (3 points) performance levels. The MSI is the weighted sum of school level achievement test scores at each of the four performance levels: 4 points for advanced," 3 points for "proficient," 2 points for "needs improvement," and 1 point for "warning."

In Table 6, Panel A we present summary statistics for the three academic measures. CPI had a mean of 72.51, MSI had a mean of 2.39 and GHM had a mean of 44.31. As shown in Panel B, there is no statistically significant difference in academic measures between the two means of boards with financially affiliated directors and without financially affiliated directors. By contrast, Panel C shows the difference between the means of boards with founders and without founders, with schools recording significantly lower levels of student achievement when there is founder representation on board.

In the next section, we present our multivariate results.

\section{Empirical Strategy}

This paper focuses on two empirical questions not yet addressed in the literature on charter schools. First, is the presence/absence of a financially affiliated director or a founder on the board associated with better financial performance of a charter school? Second, is the presence/absence of a financially affiliated director or a founder on the board associated with better academic performance of students in a charter school? The main equation of interest takes the form: 


$$
Y_{\text {it }}=\beta_{0}+\beta_{1} X_{i t}+\beta_{2} D_{i t}+\varepsilon_{\text {it }}
$$

where $Y_{\text {it }}$ measures the financial or the academic of the charter school $i$ in year $t . X_{i t}$ is the set of control variables, and $\mathrm{D}_{\mathrm{it}}$ is a dummy variable indicating the presence of a financially affiliated director or a founder on the charter school's board.

In estimating the above regression equation, we are concerned about the potential for selfselection by financially affiliated directors and founders into charter school boards, because comparison of means tests suggests that the presence of these directors on charter school boards may be non-random. Panels $\mathrm{B}$ and $\mathrm{C}$ of Table 2 report significant differences between boards with financially affiliated directors and without financially affiliated directors, as well as between boards with founders and without founders. Charter schools with financially affiliated directors on the board exhibit significantly different financial characteristics as compared to schools without (Table 2 Panel B). Lower enrollment is more prevalent in schools with financially affiliated directors on the board (346 vs. 501). However, boards in such schools have significantly higher assets per student (USD 13,244 vs. USD 7,979). We also observe significant differences in funding structures. While we find no difference in total assets, government funds/total assets and total funds/total assets for boards with financially affiliated directors and without, the former has a much higher private grants /total assets (13.75 vs. 4.58$)$ than the latter. Similarly, the private grants, private grants/total assets, and private grants/total funds of boards with financially affiliated directors are three times higher than do boards without. Differences in government funds/total funds are more modest but show a significant advantage for boards without financially affiliated directors (97.81 vs. 93.92).

The results presented in Table 2 Panel $\mathrm{C}$ show no significant differences in total assets and total enrollment in boards with founders and without founders. However, boards without founders 
have significantly higher government funds/ total assets (278 vs. 190) and total funds / total assets (289 vs. 200) than do boards with founders.

There are also significant differences in terms of student and teacher characteristics between schools with and without financially affiliated directors, and also between schools with and without founders (Table 3). For example, schools with financially affiliated directors and founders on the board serve disproportionately high percentage of minority, first language not English (FLNE), limited-English proficient (LEP), and low-income students.

Since the presence of financially affiliated directors and founders on the board does not appear to be random according to the comparison of means tests for school, student and teacher characteristics, we may be faced with a self-selection problem (Heckman, 1978). In the presence of self-selection, the OLS estimations of equation (1) would be inconsistent, because $D_{i}$ would be correlated with the error term $\mathrm{e}_{\mathrm{i}}$, resulting in biased estimators for $\beta_{2}$, and also for the other coefficients (Greene, 2003).

To resolve the extent of the bias that results from non-random assignment, we build a treatment effects model that is developed specifically to analyze the dummy endogenous variables (Heckman, 1976, 1978; Angrist, 2004). ${ }^{3}$ Under this approach the probability of receiving a treatment (i.e., assigning a financially affiliated director on the board) is modeled together with the structural outcome equation. The full model is

$$
Y_{\text {it }}=\beta_{0}+\beta_{1} X_{i t}+\beta_{2} D_{\text {it }}+e_{\text {it }}
$$

\footnotetext{
${ }^{3}$ The instrumental variables estimation is the most widely used estimation technique for empirical studies affected by the endogeneity problem. However, there is a further issue in the validity of instrumental variables estimation when one of the endogenous regressors is a dummy variable (Angrist, 1995, 2001).
} 


$$
\begin{aligned}
& \mathrm{D}_{\mathrm{it}}{ }^{*}=\delta \mathrm{Z}_{\mathrm{it}}+\mathrm{u}_{\mathrm{it}} \\
& \mathrm{D}_{\mathrm{it}}=1 \text { If } \mathrm{D}_{\mathrm{it}}{ }^{*}>0 \\
& \mathrm{D}_{\mathrm{it}}=0 \text { if } \mathrm{D}_{\mathrm{it}}{ }^{*}<0
\end{aligned}
$$

where $D_{i}$ is an endogenous dummy variable indicating whether or not a charter school includes a financially affiliated director on its board and this binary outcome is determined by a set of explanatory variables $Z_{\mathrm{i}}$ (see Greene, 2003, pp. 787-88 for details and additional references). The individual error terms, $\varepsilon_{\mathrm{i}}$ and $\mathrm{u}_{\mathrm{i}}$, are assumed to have a bivariate normal distribution:

$$
\begin{gathered}
\mathrm{e}_{\mathrm{it}} \sim \mathrm{N}(0, \sigma) \\
\mathrm{u}_{\mathrm{it}} \sim \mathrm{N}(0,1) \\
\operatorname{corr}\left(\mathrm{e}_{\mathrm{it}}, \mathrm{u}_{\mathrm{it}}\right)=\mathrm{rho}
\end{gathered}
$$

In building the treatment equation (Equation $2 b$ ), we consider the influence of incentives on the boards' selection of a financially affiliated director or a founder, as well as the incentives facing these directors as they make their decision to sit on boards of charter schools. Based on the results from the comparisons of means tests, we identify several variables that may influence this outcome: namely, school size, school age, Private Grants/Total Assets ratio, and Private Grants/Total Funds Ratio.

In theory, exclusion restrictions are not necessary in the selection model such as ours because the model is identified by non-linearity (Heckman and Navarro-Lozano, 2004). However, in 
practice, the identification issue is less clear-cut ( $\mathrm{Li}$ and Prabhala, 2007). To avoid the issue of exclusion restrictions, we use some variables in $Z_{\mathrm{i}}$ that are not part of the structural equation (equation 2a). The selection equation (equation 2b) contains "Board Size" as an explanatory variable, which is not included in the structural equation. In addition, we include a variable that measures the average distance between directors' primary employer and the charter school (distance). We believe distance is a variable that satisfies the conditions necessary to be a valid exclusion variable. That is, it is unlikely that directors' workplace distance to a charter school is related to financial performance, but board members may be more willing to join the boards of charter schools closer to their workplaces.

The test results for the significance of the correlation between the error terms of the structural and treatment equations (rho statistic) are presented throughout the study. These results form the basis of our empirical test for the presence of self-selection. A correlation coefficient significantly different from zero validates the need to correct for self-selection. In all of our specifications, we confirm that self-selection is present and thus average treatment effects (ATE) is the appropriate empirical model to use as opposed to the OLS.

\section{Empirical Results}

We present our results in three subsections. First, we consider the impact of financially affiliated directors on financial performance. Second, we examine the impact of founders on financial performance. Finally, we consider both the effects of financially affiliated directors and founders on academic performance. We report regression results based on ordinary least squares (OLS) and average treatment effect (ATE) models. 


\subsection{Financially Affiliated Directors and Financial Performance}

In Table 2 Panel A, we first stratify the sample according to the presence or absence of a financially affiliated director on the board, and test their differences in term of financial performance. The t-tests do not yield a statistically significant difference in financial performance between boards with financially affiliated board directors and boards without. The results are similar whether we look at actual surplus or estimated surplus. There is no statistically significant difference between the two board groups.

Table 4 Panel A shows the results of multivariate OLS regressions. We first examine the impact of financially affiliated board directors and control variables as indicated in the first column. In agreement with the comparison of means tests, the OLS results show that the relationship between financially affiliated directors and financial performance is not significant (Column 1). The coefficient on the financial affiliated director dummy variable is negative but statistically insignificant. The results change when we move to the average treatment effects regression (Columns 2). This column is focused primarily on financial affiliated directors and control variables. The ATE regression demonstrates a positive relationship between financially affiliated directors and financial performance. The coefficient on the financially affiliated director dummy is 47.22 and significant at the one percent level. As well, the bottom part of Table 4 Panel B shows that the correlation coefficient between the error terms of the two equations (Equations $2 a$ and $2 b$ ) is statistically significant at one percent level of confidence and negative, implying that the OLS coefficients on the financially affiliated director dummy are biased downward. Thus, the average treatment effects (ATE) is the correct model to use in analyzing the linkage between financially affiliated directors and financial performance. Intuitively, the negative correlation coefficient 
indicates that there is a negative correlation between the selection of financially affiliated directors on the board and the financial performance.

Other significant determinants of financial performance are enrollment (negative), school age (negative), estimated surplus (negative), government grants (negative), private grants (negative) and student-to-teacher ratio (positive). The coefficients on these variables are significant at the onepercent and five-percent levels. In both OLS and ATE regressions, the results show that enrollment bears no relation to financial performance. The ATE regression illustrates that financial performance decreases as a charter school gets older.

Next, we examine the estimated average treatment effects (ATE) to take into account the impact of alternative monitoring mechanisms. Tables 5 isolates the influence of financially affiliated directors on financial performance based on organizational affiliation (for-profit and non-profit) and the presence of a board member who serve as both financially affiliated director and founder. Our results show a significant positive relationship between financial performance and financially affiliated directors who have ties to both for-profit and non-profit sponsors and donors/supporters. For financially affiliated directors who have ties to for-profit sponsors, the positive and statistically significant coefficient implies a 39.06 points increase in financial performance. The coefficient on financial performance for financially affiliated directors who have ties to not-profit donors/supporters is much larger in magnitude, as measured by a 46.61 points increase. Board members who serve as both financially affiliated directors and founders also have a positive influence on financial performance. The positive and statistically significant coefficient signifies a 42.13 points increase in financial performance. The results may suggest a strong monitoring/oversight function-- and subsequent high financial performance-- provided by financially affiliated directors on charter school boards. 


\subsection{Founders on Charter School Boards and Financial Performance}

Next we analyze the presence of founders on charter school boards and their impact on financial performance. In Table 4 column 1 we present the results for the OLS regressions. The regression control variables include all of those whose descriptive statistics we report in Panel B of Tables 2 and 3. The coefficient with respect to the founder dummy is positive (2.718) but insignificant.

In Table 4 column 3, we present the results for the average treatment effects (ATE) regressions that account for self-selection of founders on charter school boards. The correlation coefficient between the error terms of the two equations (Equations $2 \mathrm{a}$ and $2 \mathrm{~b}$ ) is positive and statistically significant, implying that the OLS coefficients on the founder director dummy are biased upward. Thus, the ATE is the correct model to use in analyzing the relationship between the founders and financial performance. After controlling for self-selection, we find a negative relationship between financial performance and founders, which is statistically significant at the one percent level. The presence of a founder on the board is associated with a 39.10 points reduction in financial performance. The direction and significance of the control variables remains similar to the results for the financially affiliated directors.

\subsection{Financially Affiliated Directors, Founder Directors and Academic Performance}

Turning to Table 6, we present the results of the comparison of means tests for the three measures of academic performance: namely, Composite performance Index (CPI), percentage of students who scored "Good" or higher in math (GHM), and Math score index (MSI). These three math achievement measures are nearly perfectly correlated. Panels A and B report the effects of 
financially affiliated directors and founders on the three academic measures. The results show that boards with financially affiliated directors do not score differently than do boards without (Panel A). By contrast, boards with founders attain a lower academic performance than do boards without.

Tables 7 and 8 tabulate the results of academic performance from the OLS and ATE regressions for the three measures of academic achievement. In line with the comparison of means tests, the OLS results indicate no significant relationship between financially affiliated directors and academic performance, and a negative but statistically insignificant relationship between founders and academic performance. In Table, the OLS results indicate a decline of achievement test scores (3.81 points in GHM, .08 points in MSI, and 1.87 in CPI) for a charter school if a founder is present on the board, though not statistically significant.

In Columns 2 and 3 for each academic outcome variable, we turn to the average treatment effects regressions that control for self-selection of financially affiliated directors and founders on charter school boards. For financially affiliated directors, we find no evidence of self-selection bias, as the insignificant correlation coefficient ( $\rho$ in the table) between the error terms of the two equations. As a result, the coefficient on the financially affiliated director dummy is similar. We also do not find any significant relationship between financially affiliated directors and academic performance. We conclude that the overall presence of financially affiliated directors on charter school boards is positively related to financial performance but not to academic achievement.

The presence of founders on the board is associated with lower academic performance. Founders are associated with a reduction in academic performance of 40.07 points for GHM, .85 points for MSI, and 26.18 points for CPI. We conclude that founders adversely impact both the financial performance and academic achievement in charter schools. 
Finally, Table 8 separates the effects of financially affiliated directors on academic performance based on organizational affiliation (for-profit and non-profit) and the presence of a board member who serve as both financially affiliated director and founder. We set the results of our ATE regression for each academic outcome measure. Our results show a significant positive relationship between academic performance and financially affiliated directors who have ties to the

for-profit sponsors. By contrast, academic performance seems to be insensitive to the presence of financially affiliated directors who have ties to the non-profit donors/supporters. Board members who serve as both financially affiliated directors and founders have a positive effect on all three measures of academic achievement.

\section{Summary, Contributions and Conclusion}

The findings of this study show that the presence of financially affiliated directors on charter school boards is positively related to higher financial performance and is unrelated to lower student performance. We demonstrate the existence of a positive impact of financially affiliated directors on financial performance regardless of their organizational affiliation. While teasing out the influence of financially affiliated directors by their organizational affiliation, our results indicate that a forprofit affiliation impacts the academic performance positively whereas a non-profit affiliation has no significant impact. The presence of financially affiliated directors who are also founder-directors has a statistically significant, positive influence on both financial and academic performance. We also find that charter school founders have a negative effect on both financial and academic performance. We believe these findings have important theoretical and practical implications.

First, our results provide direct support for the findings from similar studies of donors on nonprofit boards and affiliated directors on for-profit boards, that the presence of financially 
affiliated directors on charter school boards can positively influence financial performance. Moreover, our ATE results found that the correlation coefficient between the error terms of the selectivity and treatment equation is biased downward, indicating private information leading to information asymmetry between charter schools and financially affiliated directors. Although it is precisely this private information that encourages charter schools to select financially affiliated directors on their boards, this information is negatively correlated with financial performance (Lee and Prabhala, 2006). For example, charter schools may be more inclined to include financially affiliated directors on their boards if they know that the school is not doing well financially and will need more private grants to fulfill their financial goals.

Second, the results of this study provide new insights in understanding the differential impact of financially affiliated directors by their organizational affiliation on both financial and academic outcomes. It is important to note the differential effects between financially affiliated directors with organizational ties to for-profit and those with ties to non-profit. To the best of our knowledge, this is the first empirical research to systematically examine the role and effect of financially affiliated directors on charter school performance and emphasize their connections with various organizations not usually captured in the literature on charter school governance. The range of organizations providing financial and material resources to traditional public schools and to charter schools is diverse, and our understanding is fragmentary. While private resources supporting public education are nothing new (Wohlstetter et al., 2004), there is recent interest in exploring whether nongovernment organizations such as foundation donors, are responding to incentives to increase accountability for school performance (Hansen, 2008). Our results suggest that financially affiliated directors with organizational ties to a non-profit have a positive effect on financial performance but an insignificant effect on academic performance. Research on the effect of affiliated directors on 
organizational performance has been limited to research on corporate boards of directors (Daily et al., 1999; 2003). It may be illuminating to examine if there is a need to balance representation of for-profit and non-profit affiliations of financially affiliated directors to enhance their monitoring/oversight role, in improved school performance. Future research could also examine what sets of skills and characteristics of financially affiliated directors positively influence charter school outcomes.

Third, given that one of the our most important findings is that founder directors have a negative effect on both financial and academic performance, the study is consistent with the empirical predictions implied by the entrenchment and life cycle theories that suggest the continued presence of founder directors on the board may represent a hindrance to organizational performance. This may be — and in fact often is - a hard lesson for founders with a strong personal attachment and financial stake in the charter schools they built to actually implement, but may be necessary for the continued growth and success of their schools.

Fourth, the negative impact of government funds and private grants on financial performance is consistent with prior expectations, following the literature on education production inefficiencies. Notable economists working on education, such as Hanushek (1998, 2003, 2004), have found that pouring financial resources into schools does not automatically translate into increased school effectiveness or efficiency. This suggests that charter schools that receive/utilize additional government funds or private grants do not necessarily have the incentives to fulfill their financial goals. Similarly, the findings of the present research also suggest that older charter schools may introduce a level of bureaucracy and spending that is resource intensive (increased levels of spending on administration, teachers, libraries, curriculum/instruction, building maintenance and school expansion) as compared to previous years. Thus older charter schools do not have the incentives to 
fulfill their financial targets. School size by contrast, as a proxy measure of student enrollment, has an insignificant relationship with financial performance. This finding lends support to existing evidence about the limited economies of scale achieved in the operating budgets with the number of students enrolled in a school (Andrews, Duncombe, and Yinger, 2002). These findings suggest that additional school resources alone may not result in the desired outcomes (financial and academic), and that certain types of board members are valuable, while others are not, in accomplishing the charter school performance objectives.

In closing, the current study seeks to contribute to a slowly growing body of research on charter school governance, and offers the first empirical examination of the relationship between charter school board members and financial performance. Improving the financial performance of charter school boards has implications for greater accountability at the school site. Given expanded authority and fiscal resources, decision makers (charter school boards) close to the ground should be better able to handle internal control over financial performance. Our study suggests that the linkage between board makeup and board objectives cannot be overlooked, since the presence/absence of certain board members influence different performance outcomes. 


\section{References}

Adams, R., Hermalin, B., Weisbach, M., 2010. The role of boards of directors in corporate governance: A conceptual framework and survey. Journal of Economic Literature 48, 58107.

Allgood, S., Farrell, K.A., 2000. The impact of tenure on the firm performance-CEO-turnover relation. Journal of Financial Research 23 (Fall), 373-90.

Andrews M. , Duncombe W., Yinger J., 2002. Revisiting economies of size in American education: Are we any closer to a consensus? Economics of Education Review 21 (3), 245-62.

Angrist, J., 2004. Treatment effect heterogeneity in theory and practice. The Economic Journal 114, C52-C83.

Bhagat, S., Brickley, J.A., Coles, J.L., 1987. Managerial indemnification and liability insurance: the effect on shareholder wealth. The Journal of Risk and Insurance 54, 721-236.

Brunner, E., Imazeki, J., 2003. Private contributions and public school resources. Working Papers 0011. San Diego State University Department of Economics.

Brunner, E.J., Imazeki, J., 2005. Fiscal stress and voluntary contributions to public schools. Developments in School Finance, National Center for Education Statistics 39-54.

Buddin, R., Zimmer, R., 2005. Student achievement in charter schools: A complex picture. Journal of Policy Analysis and Management, John Wiley \& Sons, Ltd. 24 (2), 351-371.

Bulkley, K., 2001. Educational performance and charter school authorizers: The accountability bind. Education Policy Analysis Archives 9, 37. available at http://epaa.asu.edu/epaa/v9n37.html.

Bulkley, K., Wohlstetter, P.A., 2003. Taking account of charter schools: What's happened and what's next? New York: Teachers College Press.

Callen, J. L., Klein, A., \& Tinkelman, D. 2003. Board composition, committees and organizational efficiency: The case of nonprofits. Nonprofit and Voluntary Sector Quarterly 32 (4), 493520.

Carnoy, M., \& Loeb., S. 2002. Does external accountability affect student outcomes: A cross-state analysis. Educational Evaluation and Policy Analysis 24, 205-331.

Center for Educational Reform, 2008. available at http://www.edreform.com/accountability/charters/CER_2008_AR_Overview.pdf/, 2008.

Center for Educational Reform, 2009. available at http://www.edreform.com/accountability/charters/CER_2009_AR_Overview.pdf/, 2009.

Churchill, N.C., Lewis, V.L., 1983. Growing concerns: The five stages of small business growth. Harvard Business Review 7 (3), 30-50.

Daily, C., Dalton, D., 1992. Financial performance of founder-managed versus professionally managed small corporations. Journal of Small Business Management 30 (2), 25-34.

Daily, C., Johnson, J., Dalton, D., 1999. On the measurements of board composition: Poor consistency and a serious mismatch of theory and operationalization. Decision Sciences 30 (1), 83-106.

Daily, C., Dalton, D., Rajagopalan, N., 2003. Governance through ownership: Centuries of practice, decades of research. Academy of Management Journal 46 (2), 151-158.

Du Bois, C., Ralf, C., Jegers, M., De Cooman, R., De Gieter, S., Pepermans, R., 2009. The link between board composition and board objectives: An empirical analysis on Flemish nonprofit schools. Managerial and Decision Economics 30, 173-182.

Fama, E., 1980. Agency problems and the theory of the firm. Journal of Political Economy 88 (2), 288-307. 
Fama, E., \& Jensen, M., 1983. Separation of ownership and control. Journal of Law and Economics $26,301-326$.

Finkelstein, S., Hambrick, D., 1996. Strategic leadership: Top executive and their effects on organizations. New York, West Publishing Company.

Finnigan, K., Adelman, N., Anderson, L., Cotton, L., Donnelly, M., Price, T., 2004. Evaluation of the public charter schools program: Final evaluation report. US Department of Education, Washington, D.C.

Gedajlovic, E., Lubatkin, M., Schulze,W., 2004. Crossing the threshold from founder management to professional management: a governance perspective. Journal of Management Studies 41 (5), 899-912.

Gewertz, C., 2008. September 8. Many charter boards seen as unprepared. Education Week. available at http://www.edweek.org/ew/articles/2010/09/10wallace-6.h28.html.

Gibbs, P. A., 1993. Determinants of Corporate Restructuring: The Relative Importance of Corporate Governance, Takeover Treat, and Free Cash Flow. Strategic Management Journal 14 (Summer Special), 51-68.

Goertz, M. E., Hess, Jr., G.A., 1998. Processes and power in school budgeting across four large urban school districts. Journal of Education Finance 23 (4), 490-506.

Goertz, M. E., Stiefel, L., 1998. (Entire Issue). School-level resource allocation in urban public schools. Journal of Education Finance 23, 4.

Greene, W.H., 2003. Econometric Analysis, 5th Edition. New Jersey, Prentice-Hall.

Greiner, L.E., 1972. Evolution and revolution as organizations grow. Harvard Business Review 50 (4), 37-46.

Hambrick, D., Crozier, L., 1985. Stumblers and stars in the management of rapid growth. Journal of Business Venturing 1, 31-45.

Hansmann, H., 1988. Ownership of the Firm. Journal of Law, Economics, \& Organization 4, 267304.

Hannaway, J., Sharkey, N., 2004. Does Profit Status Make a Difference: Resource Allocation in EMO-Run and Traditional Public Schools. Journal of Education Finance 30 (1), 27-49.

Hansen, J.S., 2008. The role of nongovernmental organizations in financing public schools. In: Ladd, H., Fiske, E. (Eds.), Handbook of research in education finance and policy. New York, Routledge.

He, L., 2008. Do founders matter? A study of executive compensation, governance structure and firm performance. Journal of Business Venturing 23, 257-279.

Heckman, J., 1976. Sample selection bias as a specification error. Econometrica 47 (1), 153-161.

Heckman, J., 1978. Dummy endogenous variables in a simultaneous equation system. Econometrica 47, 153-161.

Heckman, J., Navarro-Lozano, S., 2004. Using matching, instrumental variables, and control functions to estimate economic choice models. Review of Economics and Statistics 86, 3057.

Hofer, C.W., Charan, R., 1984. The transition to professional management: Mission impossible? American Journal of Small Business 9, 1-11.

Iatarola, P., Stiefel, L., 1998. School-based budgeting in New York City: Perceptions of school communities. Journal of Education Finance 23 (4), 557-576.

Jensen, M.C., Meckling W., 1976. Theory of the firm: Managerial behaviour, agency costs and ownership structure. Journal of Financial Economics 3 (4), 305-360. 
Lampkin, L.M., Stern, D.D., 2003. Who helps public schools: A portrait of local education funds, 1991-2001. The Urban Institute, Washington, D.C.

Levin, H., McEwan, P., 2002. Cost-Effectiveness Analysis. Thousand Oaks: Sage Publications, Inc.

Levin, H., Belfield. C., 2002. Families as Contractual Partners in Education. UCLA Law Review 49 (6), 1799-1824.

Li, K., Prabhala, N., 2006. Self-Selection models in corporate finance. In: Eckbo, B.E. (Ed.), Handbook of corporate finance: Empirical corporate finance, North Holland.

Linnell, D., 2004. Founders and Other Gods. Nonprofit Quarterly 11, 1.

McClusky, J., 2002. Rethinking nonprofit organization governance: Implications for management and leadership. International Journal of Public Administration 25, 539-559.

Miller-Millesen, J.L., 2003. Understanding the behavior of nonprofit boards of directors: A theorybased approach. Nonprofit and Voluntary Sector Quarterly 32 (4), 521-547.

Miron, G., Nelson, C., 2002. What's public about charter schools? Lessons learned about choice and accountability. Thousand Oaks, CA: Corwin Press.

Massachusetts Department of Elementary and Secondary Education, 2007. Charter school administrative and governance guide. available at http://www.doe.mass.edu/charter/governance/.

Massachusetts Department of Elementary and Secondary Education, 2010. Education laws and regulations. available at http://www.doe.mass.edu/lawsregs $/ 603 \mathrm{cmr} 1 . h t m l$.

National Alliance for Public Charter Schools, 2011. Measuring up to the model: A ranking of state public charter school laws. available at http://www.publiccharters.org/charterlaws/state/MA.

Plank, D., Smith, B., 2008. Autonomous schools: Theory, evidence and policy. In: Ladd, H., Fiske, E. (Eds.), Handbook of research in education finance and policy. New York, Routledge.

Şişli-Ciamarra, Elif, 2011. Bankers on boards: Effects on financing decision, investment decision and performance, Financial Management, forthcoming.

Smith, J., Wohlstetter, P., 2006. Understanding the different faces of partnering: A typology of public/private partnerships. School Leadership and Management 26 (3), 249-268.

Stevenson, H. H., Jarillo, J.C., 1990. A paradigm of entrepreneurship: Entrepreneurial management. Strategic Management Journal 11, Summer, Special Issue, 17-27.

Zajac, E., Westphal, J.D., 1996a. Who shall succeed? How CEO/board preferences and power affect the choice of new CEOs. Academy of Management Journal 39, 64-90.

Zajac, E.J., Westphal, J.D., 1996b. Director reputation, CEO-board power, and the dynamics of board interlocks. Administrative Science Quarterly 41, 507-529.

Zimmer, R.W., Krop, C., Brewer, D.J., 2003. Private resources in public schools: Evidence from a pilot study. Journal of Education Finance 28 (Spring), 485-522.

Willard, G.E., Krueger, D.A., Feeser, H., 1992. In order to grow, must the founder and non-founder managed high-growth manufacturing firms. Journal of Business Venturing 7, 181-194.

Wohlstetter, P., Malloy, C.L., Hentschke, G., Smith, J., 2004. Improving service delivery in education through collaboration: An exploratory study of the role of cross-sectoral alliances in the development and support of charter schools. Social Science Quarterly 85 (5), 10781096. 


\section{Appendix}

\begin{tabular}{ll} 
Variable & Definition \\
\hline Total Assets & \multicolumn{1}{c}{ A. Finance variables } \\
& $\begin{array}{l}\text { the sum of current and long-term assets owned by a } \\
\text { charter school }\end{array}$ \\
Government Funds & $\begin{array}{l}\text { sources of financial support to charter schools from all } \\
\text { three levels of government - federal, state, and local }\end{array}$ \\
Fovernment & $\begin{array}{l}\text { sources of financial support to charter schools scaled by } \\
\text { total assets }\end{array}$ \\
Private Grants & $\begin{array}{l}\text { includes private money and material support from non- } \\
\text { profit and for-profit sources. This variable includes all } \\
\text { funds raised from private sources that can be used as part } \\
\text { of the school's operating revenues }\end{array}$
\end{tabular}

Private Grants/

Total Assets

all funds provided through private sources scaled by total assets

Total Funds

(Government Funds

government funds in addition to private grants that are

+ Private Grants) used for the school's annual operating budget

Total Funds /Total combination of government funds and private grants Assets divided by total assets

Private Grants/ $\quad$ private grants divided by total funds Total Funds

Government
Funds/Total Funds

government funds divided by total funds

Actual actual total revenues minus actual total expenses scaled Surplus/Total Assets by total assets

Estimated projected total annual revenues minus projected total Surplus/Total Assets annual expenses scaled by total assets 
Financial the difference between the estimated surplus in a given

Performance year minus the actual surplus for that year scaled by total assets

Debt Ratio ratio of total debt (the sum of current liabilities and longterm liabilities) and total assets

\begin{tabular}{l} 
\\
\hline Composite \\
Performance Index \\
(cpi)
\end{tabular}

B. Achievement variables

a measure of the extent to which students are progressing toward proficiency in English language arts (ELA) and mathematics, respectively. The CPI is a 100-point index that combines the scores of students who take standard MCAS tests (the Proficiency Index) with the scores of those who take the MCAS-Alternate Assessment (MCAS-Alt) (the MCAS-Alt Index)

$\%$ of Good Math the weighted sum of school level achievement test scores Scores at the advanced ( 4 points) and proficient ( 3 points) performance levels

Math Score Index an aggregated index of achievement (calculation: 4 for advanced, 3 for proficient, 2 for needs improvement, \& 1 for warning. Then calculated a weighted average of scores)

\begin{tabular}{|c|c|}
\hline \multicolumn{2}{|r|}{ C. School variables } \\
\hline $\begin{array}{l}\text { \% of Low Income } \\
\text { Students }\end{array}$ & $\begin{array}{l}\text { the percentage of enrolment who meet any one of the } \\
\text { following definitions of low-income: the student is } \\
\text { eligible for free or reduced price lunch; or the student } \\
\text { receives Transitional Aid to Families benefits; or } \\
\text { the student is eligible for food stamps }\end{array}$ \\
\hline$\%$ of Black Students & the percentage of enrolment for black/African Americans \\
\hline$\%$ of Asian Students & the percentage of enrolment for Asians/Pacific Islanders \\
\hline $\begin{array}{l}\text { \% of Hispanic } \\
\text { Students }\end{array}$ & the percentage of enrolment for Hispanics \\
\hline $\begin{array}{l}\% \text { of Native } \\
\text { American Students }\end{array}$ & $\begin{array}{l}\text { the percentage of enrolment for American Indians/Alaska } \\
\text { Natives }\end{array}$ \\
\hline
\end{tabular}


$\%$ of Non-native

English Speakers

$\%$ of Female

Students

$\%$ with Limited

English Proficiency

$\%$ of Special

Education Students

$\%$ of Licensed

Teachers

$\%$ of Qualified

Teachers

Student-to-Teacher

Ratio

Elementary School

Middle School

High School

Log(Enrollment)

Log(School Age)

\begin{tabular}{l}
\hline \\
\hline Financially \\
Affiliated Director
\end{tabular}

Founder Director the percentage of enrolment whose first language is a language other than English

percentage of female enrolment

the percentage of students whose first language is a language other than English and who are unable to perform ordinary classroom work in English

the percentage of enrolment with Individualized Education Program (IEP)

percentage of teachers licensed in teaching assignment

percentage of core academic classes taught by teachers who are highly qualified

the ratio of full-time-equivalent students to full-timeequivalent teachers

dummy variables indicating whether the charter school is elementary school or not

dummy variables indicating whether the charter school is middle school or not

dummy variables indicating whether the charter school is high school or not

the log of the total number of students enrolled at a charter school

the log of the number of years the charter school has been in operation

\section{Board Director variables} dummy variable indicating the presence of at least one financially affiliated director on the charter school board

dummy variable indicating the presence of at least one founder on the charter school board 
Financial Affiliation dummy variable indicating the presence of at least one with For-profit financially affiliated director with organizational ties to a for-profit organization

Financial Affiliation dummy variable indicating the presence of at least one with Non-profit financially affiliated director with organizational ties to a non-profit organization

Financially dummy variable indicating the presence of at least one Affiliated and board member who is both a financially affiliated director Founder and a founder on the charter school's board

Log(Board size) the log of the total number of directors on the charter school board

Distance average distance in miles between each director's workplace location and charter school location (aggregated at the school level) 


\section{Table 1A}

Board of director characteristics, 2001-2009.

\begin{tabular}{|c|c|c|c|c|c|}
\hline & Obs. & Mean & $\begin{array}{c}\text { Standard } \\
\text { Deviation } \\
\end{array}$ & Minimum & Maximum \\
\hline \multicolumn{6}{|l|}{ 2001-2009 } \\
\hline Board Size & 485 & 11.76 & 3.99 & 4 & 28 \\
\hline Number of Financially Affiliated Directors on Board & 485 & 1.90 & 1.99 & 0 & 11 \\
\hline Number of Founders on Board & 485 & 1.96 & 1.98 & 0 & 12 \\
\hline$\%$ of Boards with a Financially Affiliated Director & 485 & 0.70 & 0.46 & 0 & 1 \\
\hline$\%$ of boards with a Financially Affiliated Director (For-profit) & 485 & 0.19 & 0.39 & 0 & 1 \\
\hline$\%$ of boards with a Financially Affiliated Director (Non-profit) & 485 & 0.64 & 0.48 & 0 & 1 \\
\hline$\%$ of Boards with a Founder-Director & 485 & 0.75 & 0.43 & 0 & 1 \\
\hline $\begin{array}{l}\% \text { of boards with a Financially Affiliated Director who is also a } \\
\text { founder }\end{array}$ & 485 & 0.29 & 0.46 & 0 & 1 \\
\hline
\end{tabular}

Notes: This table presents the summary statistics for the MA charter school board of directors for 2001-2009. Data is hand-collected by the authors. Board size is the number of directors serving on a charter school's board of directors. Financially affiliated directors are board members with direct ties to locally-based voluntary contributors, independent foundations and sponsors by serving as a staff member, executive, or on a board of directors. Founders are board members who had been responsible for securing basic financial and material needs for the school during the pre-approval and pre-operational stages of charter school development. 


\section{Table 1B}

Evolution of charter school boards, 2001-2009.

\begin{tabular}{|c|c|c|c|c|c|c|}
\hline & Obs. & Board Size & $\begin{array}{c}\text { Number of } \\
\text { Financially } \\
\text { Affiliated } \\
\text { Directors }\end{array}$ & $\begin{array}{l}\text { Number of } \\
\text { Founder- } \\
\text { Directors }\end{array}$ & $\begin{array}{c}\% \text { of Boards } \\
\text { with a } \\
\text { Financially } \\
\text { Affiliated } \\
\text { Director }\end{array}$ & $\begin{array}{c}\% \text { of Boards } \\
\text { with a } \\
\text { Founder- } \\
\text { Director }\end{array}$ \\
\hline 2001 & 41 & 11.73 & 2.10 & 2.83 & 0.71 & 0.90 \\
\hline 2002 & 46 & 11.52 & 1.89 & 2.30 & 0.68 & 0.85 \\
\hline 2003 & 49 & 12.00 & 1.92 & 2.10 & 0.76 & 0.76 \\
\hline 2004 & 55 & 11.84 & 1.78 & 2.27 & 0.74 & 0.81 \\
\hline 2005 & 56 & 12.05 & 1.66 & 1.93 & 0.67 & 0.78 \\
\hline 2006 & 58 & 11.79 & 1.59 & 1.84 & 0.66 & 0.73 \\
\hline 2007 & 60 & 11.68 & 1.57 & 1.72 & 0.70 & 0.67 \\
\hline 2008 & 60 & 11.55 & 1.52 & 1.45 & 0.69 & 0.62 \\
\hline 2009 & 60 & 11.67 & 1.47 & 1.45 & 0.66 & 0.64 \\
\hline
\end{tabular}

Figure 1. Evolution of charter school boards, 2001-2009.

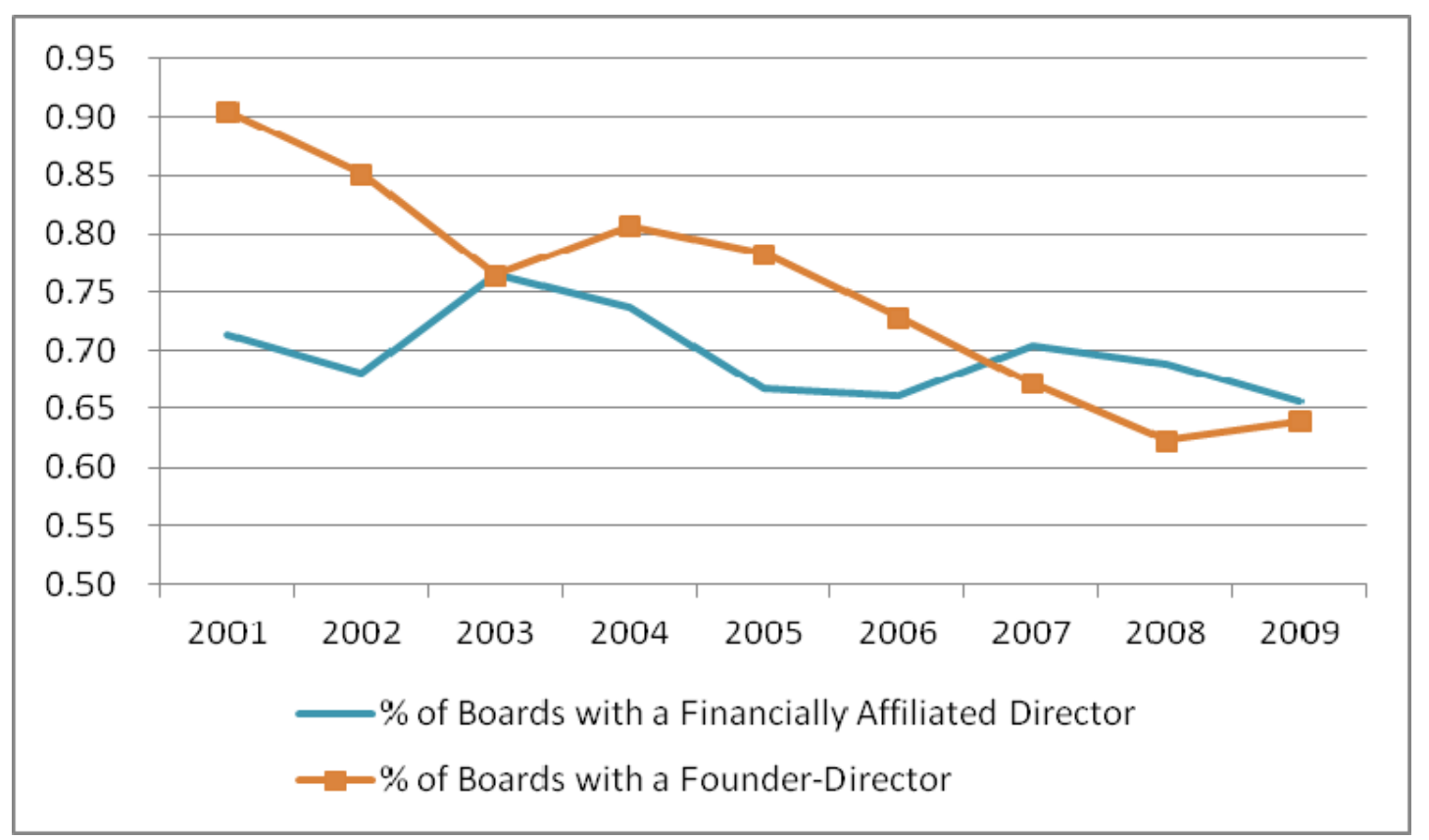


Table 2: Summary Statistics and Comparisons of Means Tests for Finance Variables by Board Type

Panel A. Summary Statistics

\begin{tabular}{lrrrrr}
\hline & Obs & Mean & Std. Dev. & Min & Max \\
\hline \hline School Size & & & & & \\
Total Assets & 478 & $4,909,835$ & $8,177,130$ & 51,132 & $68,200,000$ \\
Enrollment & 485 & 393 & 322 & 25 & 1,574 \\
Total Assets / Enrollment & 478 & 11,680 & 16,319 & 413 & 111,988 \\
Funds & & & & & \\
Government Funds & 477 & $4,499,654$ & $3,595,141$ & 374,315 & $18,000,000$ \\
Government Funds / Total Assets & 476 & 256 & 281 & 12 & 2,988 \\
Private Grants & 477 & 192,365 & 363,093 & 0 & $3,443,937$ \\
Private Grants / Total Assets & 476 & 11 & 29 & 0 & 328 \\
Total Funds (Government+ Private) & 477 & $4,692,018$ & $3,618,965$ & 374,315 & $19,900,000$ \\
Total Funds / Total Assets & 476 & 267 & 291 & 17 & 2,988 \\
Private Grants / Total Funds & 477 & 4.92 & 7.85 & 0.00 & 47.87 \\
Government Funds / Total Funds & 477 & 95.08 & 7.85 & 52.13 & 100.00 \\
Financial Performance & & & & & \\
Actual Surplus / Total Assets & 476 & 6.03 & 32.23 & -196.73 & 417.81 \\
Estimated Surplus / Total Assets & 470 & 4.64 & 16.47 & -143.04 & 110.80 \\
Financial Performance & 468 & 1.08 & 31.71 & -187.31 & 388.30 \\
Debt Ratio & 478 & 16.78 & 28.55 & 0.00 & 143.75 \\
\hline
\end{tabular}

Notes: All variables are described in detail in the Appendix. 
Table 2: Summary Statistics and Comparisons of Means Tests for Finance Variables by Board Type (cont'd)

Panel B. Comparison of Means Tests for Presence of Financially Affiliated Directors

\begin{tabular}{|c|c|c|c|c|}
\hline & $\begin{array}{c}\text { Financially } \\
\text { Affiliated } \\
\text { Director } \\
\text { Present on } \\
\text { Board } \\
\end{array}$ & $\begin{array}{l}\text { Financially } \\
\text { Affiliated } \\
\text { Director not } \\
\text { Present on } \\
\text { Board }\end{array}$ & $\begin{array}{l}\text { Hypothesis: } \\
\text { Equal means } \\
\text { (Prob>t) }\end{array}$ & $\begin{array}{c}\text { Significance } \\
\text { Level }\end{array}$ \\
\hline \multicolumn{5}{|l|}{ School Size } \\
\hline Total Assets & $4,958,110$ & $4,795,607$ & 0.843 & \\
\hline Enrollment & 346 & 501 & 0.000 & $* * *$ \\
\hline Total Assets / Enrollment & 13,244 & 7,979 & 0.001 & $* * *$ \\
\hline \multicolumn{5}{|l|}{ Funds } \\
\hline Government Funds & $4,184,206$ & $5,243,844$ & 0.003 & $* *$ \\
\hline Government Funds / Total Assets & 264 & 238 & 0.359 & \\
\hline Private Grants & 235,821 & 89,846 & 0.000 & $* * *$ \\
\hline Private Grants / Total Assets & 13.75 & 4.58 & 0.002 & $* *$ \\
\hline Total Funds (Government+ Private) & $4,420,026$ & $5,333,690$ & 0.012 & $* *$ \\
\hline Total Funds / Total Assets & 277 & 242 & 0.230 & \\
\hline Private Grants / Total Funds & 6.08 & 2.19 & 0.000 & $* * *$ \\
\hline Government Funds / Total Funds & 93.92 & 97.81 & 0.000 & $* * *$ \\
\hline \multicolumn{5}{|l|}{ Financial Performance } \\
\hline Actual Surplus / Total Assets & 4.56 & 9.49 & 0.127 & \\
\hline Estimated Surplus / Total Assets & 4.78 & 4.32 & 0.780 & \\
\hline Financial Performance & -0.71 & 5.18 & 0.065 & \\
\hline Debt Ratio & 16.11 & 18.37 & 0.430 & \\
\hline
\end{tabular}

Notes: All variables are described in detail in the Appendix.

*** Significant at the 0.001 level

** Significant at the 0.01 level

* Significant at the 0.05 level 
Table 2: Summary Statistics and Comparisons of Means Tests for Finance Variables by Board Type (cont'd)

Panel C. Comparison of Means Tests for Presence of Founders

\begin{tabular}{lrrrr}
\hline & $\begin{array}{c}\text { Founder } \\
\text { present on } \\
\text { Board }\end{array}$ & $\begin{array}{c}\text { Founder not } \\
\text { present on } \\
\text { Board }\end{array}$ & $\begin{array}{c}\text { Hypothesis: } \\
\text { Equal means } \\
\text { (Prob>t) }\end{array}$ & $\begin{array}{c}\text { Significance } \\
\text { Level }\end{array}$ \\
\hline \hline School Size & & & & \\
Total Assets & $4,603,336$ & $5,824,224$ & 0.157 & \\
Enrollment & 399 & 374 & 0.464 & \\
Total Assets / Enrollment & 11,037 & 13,600 & 0.137 & \\
Funds & & & & \\
Government Funds & $4,538,818$ & $4,380,501$ & 0.679 & \\
Government Funds / Total Assets & 278 & 190 & 0.003 & $*$ \\
Private Grants & 175,036 & 245,085 & 0.069 & \\
Private Grants / Total Assets & 11.38 & 9.90 & 0.629 & \\
Total Funds (Government+ Private) & $4,713,854$ & $4,625,587$ & 0.819 & \\
Total Funds / Total Assets & 289 & 200 & 0.004 & \\
Private Grants / Total Funds & 4.66 & 5.73 & 0.199 & \\
Government Funds / Total Funds & 95.34 & 94.27 & 0.199 & \\
Financial Performance & & & & \\
Actual Surplus / Total Assets & 7.13 & 2.70 & 0.196 & $*$ \\
Estimated Surplus / Total Assets & 5.69 & 1.50 & 0.017 & $*$ \\
Financial Performance & 1.09 & 1.04 & 0.989 & \\
Debt Ratio & 15.91 & 19.37 & 0.252 & \\
\hline
\end{tabular}

Notes: All variables are described in detail in the Appendix.

*** Significant at the 0.001 level

** Significant at the 0.01 level

* Significant at the 0.05 level 
Table 3. Summary Statistics and Comparison of Means Tests for Student and Teacher characteristics by Board Type

Panel A. Summary Statistics

\begin{tabular}{lrrrrr}
\hline & & & Std. & & \\
& Obs & Mean & \multicolumn{1}{c}{ Dev. } & Min & Max \\
\hline \hline Student Characteristics & & & & & \\
\% of Low income students & 484 & 45.25 & 28.57 & 0.00 & 100.00 \\
\% of Black Students & 485 & 29.05 & 31.15 & 0.00 & 97.00 \\
\% of Asian Students & 485 & 3.26 & 5.94 & 0.00 & 62.10 \\
\% of Hispanic Students & 485 & 18.74 & 21.77 & 0.00 & 99.40 \\
\% of Female Students & 485 & 51.11 & 6.23 & 24.00 & 79.00 \\
\% of Non-native English Speakers & 485 & 14.22 & 20.07 & 0.00 & 100.00 \\
\% of students with Limited English Proficiency & 485 & 2.72 & 7.20 & 0.00 & 48.50 \\
\% of Special Education Students & 485 & 13.43 & 7.24 & 2.30 & 60.00 \\
Teacher Characteristics & & & & & \\
Number of Teachers & 485 & 32.41 & 22.61 & 1.00 & 112.00 \\
\% of Licensed Teachers & 485 & 62.12 & 22.61 & 0.00 & 100.00 \\
\% of Qualified Teachers & 485 & 82.64 & 19.82 & 0.00 & 100.00 \\
Student-to-Teacher Ratio & 485 & 11.85 & 2.52 & 5.80 & 22.40 \\
\hline
\end{tabular}

Notes: All variables are described in detail in the Appendix. 
Table 3. Summary Statistics and Comparison of Means Tests for Student and Teacher characteristics by Board Type (cont'd)

Panel B. Comparison of Means Tests for Presence of Financially Affiliated Directors

\begin{tabular}{|c|c|c|c|c|}
\hline & $\begin{array}{c}\text { Financially } \\
\text { Affiliated } \\
\text { Director } \\
\text { Present on } \\
\text { Board } \\
\end{array}$ & $\begin{array}{l}\text { Financially } \\
\text { Affiliated } \\
\text { Director not } \\
\text { Present on } \\
\text { Board } \\
\end{array}$ & $\begin{array}{l}\text { Hypothesis: } \\
\text { Equal means } \\
\text { (Prob>t) }\end{array}$ & $\begin{array}{c}\text { Significance } \\
\text { Level }\end{array}$ \\
\hline \multicolumn{5}{|l|}{ "Student Characteristics } \\
\hline$\%$ of Low Income Students & 51.74 & 30.08 & 0.0000 & $* * *$ \\
\hline$\%$ of Black Students & 34.15 & 17.07 & 0.0000 & $* * *$ \\
\hline$\%$ of Asian Students & 3.36 & 3.02 & 0.5623 & \\
\hline$\%$ of Hispanic Students & 20.11 & 15.51 & 0.0328 & $*$ \\
\hline$\%$ of Male Students & 48.52 & 49.79 & 0.0399 & * \\
\hline$\%$ of Non-native English Speakers & 16.62 & 8.59 & 0.0000 & $* * *$ \\
\hline$\%$ of Students with Limited English Proficiency & 3.05 & 1.96 & 0.1246 & \\
\hline$\%$ of Special Education Students & 13.61 & 12.99 & 0.3848 & \\
\hline \multicolumn{5}{|l|}{ Teacher Characteristics } \\
\hline Number of Teachers & 29.74 & 38.65 & 0.0001 & $* * *$ \\
\hline$\%$ of Licensed Teachers & 62.63 & 60.94 & 0.4525 & \\
\hline$\%$ of Qualified Teachers & 83.84 & 79.81 & 0.0405 & * \\
\hline Student-to-Teacher Ratio & 11.56 & 12.50 & 0.0002 & $* * *$ \\
\hline
\end{tabular}

Notes: All variables are described in detail in the Appendix.

*** Significant at the 0.001 level

** Significant at the 0.01 level

* Significant at the 0.05 level 
Table 3. Summary Statistics and Comparison of Means Tests for Student and Teacher characteristics by Board Type (cont'd)

Panel C. Comparison of Means Tests for Presence of Founders

\begin{tabular}{|c|c|c|c|c|}
\hline & $\begin{array}{c}\text { Founder } \\
\text { present on } \\
\text { Board } \\
\end{array}$ & $\begin{array}{c}\text { Founder not } \\
\text { present on } \\
\text { Board }\end{array}$ & $\begin{array}{c}\text { Hypothesis: } \\
\text { Equal means } \\
\text { (Prob>t) }\end{array}$ & $\begin{array}{c}\text { Significance } \\
\text { Level }\end{array}$ \\
\hline \multicolumn{5}{|l|}{ Student Characteristics } \\
\hline$\%$ of Low Income Students & 48.67 & 34.87 & 0.0000 & $* * *$ \\
\hline$\%$ of Black Students & 31.54 & 21.56 & 0.0022 & $* *$ \\
\hline$\%$ of Asian Students & 3.66 & 2.06 & 0.0102 & $* *$ \\
\hline$\%$ of Hispanic Students & 20.88 & 12.29 & 0.0002 & $* * *$ \\
\hline$\%$ of Male Students & 48.44 & 50.26 & 0.0053 & $* *$ \\
\hline$\%$ of Non-native English Speakers & 16.09 & 8.60 & 0.0003 & $* * *$ \\
\hline$\%$ of Students with Limited English Proficiency & 3.12 & 1.54 & 0.0363 & * \\
\hline$\%$ of Special Education Students & 13.15 & 14.26 & 0.1432 & \\
\hline \multicolumn{5}{|l|}{ Teacher Characteristics } \\
\hline Number of Teachers & 32.84 & 31.09 & 0.4590 & \\
\hline$\%$ of Licensed Teachers & 61.49 & 64.02 & 0.2856 & \\
\hline$\%$ of Qualified Teachers & 81.07 & 87.35 & 0.0025 & $* *$ \\
\hline Student-to-Teacher Ratio & 11.88 & 11.75 & 0.6403 & \\
\hline
\end{tabular}

Notes: All variables are described in detail in the Appendix.

*** Significant at the 0.001 level

** Significant at the 0.01 level

* Significant at the 0.05 level 
TABLE 4. Multivariate Analyses of Financial Performance

Panel A. Financial Performance

\begin{tabular}{|c|c|c|c|}
\hline \multirow[b]{2}{*}{ Estimation Method: } & \multicolumn{3}{|c|}{ Financial Performance } \\
\hline & OLS & ATE & ATE \\
\hline \multirow{2}{*}{ Financially Affiliated Director } & -1.211 & $47.22 * * *$ & \\
\hline & $(-0.37)$ & $(7.07)$ & \\
\hline \multirow[t]{2}{*}{ Founder Director } & 2.718 & & $-39.10 * * *$ \\
\hline & $(1.07)$ & & $(-3.48)$ \\
\hline \multirow[t]{2}{*}{ Log (Total Enrollment) } & 4.583 & $12.19^{*}$ & 7.410 \\
\hline & $(1.94)$ & $(2.33)$ & $(1.86)$ \\
\hline \multirow{2}{*}{ Log (School Age) } & -4.676 & $-9.505 * *$ & $-13.97 * * *$ \\
\hline & $(-1.66)$ & $(-2.86)$ & $(-4.10)$ \\
\hline \multirow[t]{2}{*}{ Estimated Surplus / Total Assets } & $-0.506^{* *}$ & $-0.465 * * *$ & $-0.533 * * *$ \\
\hline & $(-3.42)$ & $(-4.65)$ & $(-4.11)$ \\
\hline \multirow[t]{2}{*}{ Government Funds / Total Assets } & $-0.0396 * * *$ & $-0.0249 * * *$ & $-0.0459 * * *$ \\
\hline & $(-4.70)$ & $(-3.36)$ & $(-5.89)$ \\
\hline \multirow[t]{2}{*}{ Private Grants / Total Assets } & -0.0907 & $-0.119 *$ & -0.134 \\
\hline & $(-1.32)$ & $(-2.21)$ & $(-1.68)$ \\
\hline \multirow[t]{2}{*}{ Debt Ratio } & $-0.239 * * *$ & $-0.236^{* * *}$ & $-0.232 * * *$ \\
\hline & $(-4.86)$ & $(-4.90)$ & $(-4.84)$ \\
\hline \multirow[t]{2}{*}{ Elementary School } & 4.583 & $12.19^{*}$ & 7.410 \\
\hline & $(1.94)$ & $(2.33)$ & $(1.86)$ \\
\hline \multirow[t]{2}{*}{ Middle School } & -4.676 & $-9.505 * *$ & $-13.97 * * *$ \\
\hline & $(-1.66)$ & $(-2.86)$ & $(-4.10)$ \\
\hline \multirow[t]{2}{*}{ High School } & $-0.506 * *$ & $-0.465 * * *$ & $-0.533 * * *$ \\
\hline & $(-3.42)$ & $(-4.65)$ & $(-4.11)$ \\
\hline \multirow[t]{2}{*}{ Percentage of Licensed Teachers } & $-0.0396 * * *$ & $-0.0249 * * *$ & $-0.0459 * * *$ \\
\hline & $(-4.70)$ & $(-3.36)$ & $(-5.89)$ \\
\hline \multirow[t]{2}{*}{ Percentage of Qualified Teachers } & -0.0907 & $-0.119^{*}$ & -0.134 \\
\hline & $(-1.32)$ & $(-2.21)$ & $(-1.68)$ \\
\hline \multirow[t]{2}{*}{ Student-Teacher Ratio } & $-0.239 * * *$ & $-0.236^{* * *}$ & $-0.232 * * *$ \\
\hline & $(-4.86)$ & $(-4.90)$ & $(-4.84)$ \\
\hline \multirow{2}{*}{ Percentage of Low Income Students } & 0.0275 & -0.00266 & 0.0250 \\
\hline & $(0.60)$ & $(-0.06)$ & $(0.61)$ \\
\hline \multirow[t]{2}{*}{ Constant } & -25.82 & $-93.91 * *$ & 13.76 \\
\hline & $(-1.18)$ & $(-2.76)$ & $(0.74)$ \\
\hline
\end{tabular}

Notes: This table presents the results from the OLS and Average Treatment Effects (ATE) regressions. Panel A presents the results for the structural equation (Equation 2a in the text). The dependent variable in Panel A is Financial Performance, measured as the difference between the actual surplus in a given year and the estimated surplus for that year scaled by total assets. Data are as described in the Appendix. Panel B presents the results for the treatment equation that predicts the presence of financially affiliated or founder-directors on charter school boards (Equation $2 b$ in the text). All regressions are clustered at the charter school level and include year dummies.

*** Significant at the 0.001 level

** Significant at the 0.01 level

* Significant at the 0.05 level 
TABLE 4. Multivariate Analyses of Financial Performance

Panel B. Selection Equation

\begin{tabular}{lccc}
\hline Estimation Method: & OLS & ATE & ATE \\
\hline & & $\begin{array}{c}\text { Financially } \\
\text { Affiliated } \\
\text { Director }\end{array}$ & Founder-Director \\
Dependent Variable: & & $-0.417^{* *}$ & 0.126 \\
\hline \hline Log (Enrollment) & na & $(-2.84)$ & $(0.81)$ \\
Log (School Age) & na & 0.172 & $-0.831^{* *}$ \\
& & $(1.27)$ & $(-2.96)$ \\
Log (Board Size) & na & 0.0996 & -0.0674 \\
& & $(0.65)$ & $(-0.34)$ \\
Private Grants / Total Funds & na & $0.0345 * *$ & -0.0133 \\
& & $(2.79)$ & $(-1.49)$ \\
Distance & na & 0.00653 & -0.0109 \\
& & $(0.93)$ & $(-0.91)$ \\
Constant & na & $2.034 *$ & 1.880 \\
& & $(2.43)$ & $(1.60)$ \\
\hline N & 467 & 467 & 467 \\
Rho & na & -0.95 & 0.85 \\
Wald test of indep. Eqns.: Prob $>$ chi2 & na & $0.0000^{* * *}$ & $0.0000^{* * *}$ \\
Overall Fit of the Model: Prob $>$ chi2 & na & 0.0000 & 0.0000 \\
\hline
\end{tabular}

Notes: This table presents the results from the OLS and Average Treatment Effects (ATE) regressions. Panel B presents the results for the treatment equation that predicts the presence of financially affiliated or founder-directors on charter school boards (Equation $2 \mathrm{~b}$ in the text). All regressions are clustered at the charter school level and include year dummies. Data are as described in the Appendix.

*** Significant at the 0.001 level

** Significant at the 0.01 level

* Significant at the 0.05 level 
Table 5. Multivariate Analyses of Financial Performance for Different Types of Financially Affiliated Directors

\begin{tabular}{|c|c|c|c|}
\hline \multirow[b]{2}{*}{ Estimation Method } & \multicolumn{3}{|c|}{ Financial Performance } \\
\hline & ATE & ATE & ATE \\
\hline Financial Affiliation with For-profit & $\begin{array}{c}39.06 * * * \\
(3.61)\end{array}$ & \multirow{3}{*}{$\begin{array}{c}46.61 * * * \\
(5.85)\end{array}$} & \\
\hline Financial Affiliation with Non-Profit & & & \\
\hline Financially Affiliated and Founder & & & $\begin{array}{c}42.13 * * * \\
(3.74)\end{array}$ \\
\hline \multirow{2}{*}{ Log (Total Enrollment) } & 3.455 & $14.56 * *$ & $10.47^{*}$ \\
\hline & $(1.04)$ & $(2.72)$ & $(1.96)$ \\
\hline \multirow[t]{2}{*}{ Log (School Age) } & $-5.779 *$ & $-12.68 * * *$ & -6.027 \\
\hline & $(-2.13)$ & $(-3.62)$ & $(-1.47)$ \\
\hline \multirow[t]{2}{*}{ Estimated Surplus / Total Assets } & $-0.460 * * *$ & $-0.555 * * *$ & $-0.510 * * *$ \\
\hline & $(-3.53)$ & $(-4.42)$ & $(-3.78)$ \\
\hline \multirow[t]{2}{*}{ Government Funds / Total Assets } & $-0.0428 * * *$ & $-0.0352 * * *$ & $-0.0360 * * *$ \\
\hline & $(-5.86)$ & $(-3.63)$ & $(-3.99)$ \\
\hline \multirow[t]{2}{*}{ Private Grants / Total Assets } & $-0.193 *$ & $-0.113 *$ & -0.117 \\
\hline & $(-2.08)$ & $(-1.98)$ & $(-1.95)$ \\
\hline \multirow[t]{2}{*}{ Debt Ratio } & $-0.255^{* * *}$ & $-0.249 * * *$ & $-0.247 * * *$ \\
\hline & $(-5.17)$ & $(-5.08)$ & $(-5.04)$ \\
\hline \multirow[t]{2}{*}{ Elementary School } & -0.328 & 1.095 & -0.251 \\
\hline & $(-0.10)$ & $(0.33)$ & $(-0.07)$ \\
\hline \multirow[t]{2}{*}{ Middle School } & 1.562 & 5.566 & 5.183 \\
\hline & $(0.44)$ & $(1.44)$ & $(1.45)$ \\
\hline \multirow[t]{2}{*}{ High School } & 0.386 & 3.374 & 2.696 \\
\hline & $(0.17)$ & $(1.14)$ & $(0.86)$ \\
\hline \multirow[t]{2}{*}{ Percentage of Licensed Teachers } & -0.0492 & -0.0389 & -0.0664 \\
\hline & $(-0.63)$ & $(-0.52)$ & $(-0.81)$ \\
\hline \multirow[t]{2}{*}{ Percentage of Qualified Teachers } & 0.0867 & 0.0523 & 0.0488 \\
\hline & $(1.02)$ & $(0.68)$ & $(0.64)$ \\
\hline \multirow[t]{2}{*}{ Student-Teacher Ratio } & 0.822 & $1.147^{*}$ & 0.951 \\
\hline & $(1.46)$ & $(2.04)$ & $(1.64)$ \\
\hline \multirow[t]{2}{*}{ Percentage of Low Income Students } & 0.00452 & 0.0250 & 0.0142 \\
\hline & $(0.12)$ & $(0.53)$ & $(0.30)$ \\
\hline \multirow[t]{2}{*}{ Constant } & -14.56 & $-94.34 *$ & -61.72 \\
\hline & $(-0.65)$ & $(-2.51)$ & $(-1.85)$ \\
\hline $\mathrm{N}$ & 467 & 467 & 467 \\
\hline rho & -0.86 & -0.90 & -0.85 \\
\hline Wald test of indep. Eqns.: Prob $>$ chi2 & $0.0001 * * *$ & $0.0000 * * *$ & $0.0001 * * *$ \\
\hline Overall Fit of the Model: Prob > chi2 & 0.0000 & 0.0000 & 0.0000 \\
\hline
\end{tabular}

Notes: This table presents the results from the Average Treatment Effects (ATE) for different types of financially affiliated directors. The dependent variable in is Financial Performance, measured as the difference between the actual surplus in a given year and the estimated surplus for that year scaled by total assets. Data are as described in the Appendix. All regressions are clustered at the charter school level and include year dummies.

*** Significant at the 0.001 level

** Significant at the 0.01 level

* Significant at the 0.05 level 
Table 6. Summary Statistics and Comparison of Means Tests for Academic Achievement by Board Type

Panel A. Summary Statistics

\begin{tabular}{lrrrrr}
\hline & Obs & \multicolumn{1}{c}{ Mean } & Std. Dev. & Min & Max \\
\hline \hline Academic Performance & & & & & \\
Composite Performance Index (cpi) & 363 & 72.51 & 16.02 & 25.00 & 100.00 \\
\% of Good Math Scores & 435 & 44.31 & 25.16 & 0.00 & 100.00 \\
Math Score Index & 435 & 2.39 & 0.56 & 1.00 & 3.95 \\
\hline
\end{tabular}

Notes: This table presents the summary statistics for achievement variables. The variables are described in detail in the Appendix.

Panel B. Comparison of Means Tests for Presence of Financially Affiliated Directors

\begin{tabular}{lrrrr}
\hline & $\begin{array}{c}\text { Financially } \\
\text { Affiliated } \\
\text { Director } \\
\text { Present on } \\
\text { Board }\end{array}$ & $\begin{array}{c}\text { Financially } \\
\text { Affiliated } \\
\text { Director not } \\
\text { Present on } \\
\text { Board }\end{array}$ & $\begin{array}{c}\text { Hypothesis: } \\
\text { Equal means } \\
\text { (Prob>t) }\end{array}$ & $\begin{array}{c}\text { Significance } \\
\text { Level }\end{array}$ \\
\hline \hline Academic Performance & & & & \\
Composite Performance Index (cpi) & 72.11 & 73.43 & 0.47 \\
\% of Good Math Scores & 43.23 & 46.84 & 0.17 \\
Math Score Index & 2.37 & 2.37 & 0.16 \\
\hline
\end{tabular}

Panel C. Comparison of Means Tests for Presence of Founders

\begin{tabular}{lrrrr}
\hline & $\begin{array}{c}\text { Founder } \\
\text { present on } \\
\text { Board }\end{array}$ & $\begin{array}{c}\text { Founder not } \\
\text { present on } \\
\text { Board }\end{array}$ & $\begin{array}{c}\text { Hypothesis: } \\
\text { Equal means } \\
\text { (Prob>t) }\end{array}$ & $\begin{array}{c}\text { Significance } \\
\text { Level }\end{array}$ \\
\hline \hline Academic Performance & & & & \\
Composite Performance Index (cpi) & 70.28 & 77.83 & 0.0000 & $* * *$ \\
\% of Good Math Scores & 41.02 & 53.27 & 0.0000 & $* * *$ \\
Math Score Index & 2.31 & 2.60 & 0.0000 & $* * *$ \\
\hline
\end{tabular}

*** Significant at the 0.001 level 
Table 7. Multivariate Analyses of Academic Performance

\begin{tabular}{|c|c|c|c|c|c|c|c|c|c|}
\hline \multirow{2}{*}{$\begin{array}{l}\text { Dependent Variable } \\
\text { Estimation Method: }\end{array}$} & \multicolumn{3}{|c|}{ Math Good Percentage } & \multicolumn{3}{|c|}{ Math Score Index } & \multicolumn{3}{|c|}{$\mathrm{CPI}$} \\
\hline & OLS & ATE & ATE & OLS & ATE & ATE & OLS & ATE & ATE \\
\hline \multicolumn{10}{|l|}{ BOARD MEMBERS } \\
\hline Financially Affiliated Director & $\begin{array}{l}2.203 \\
(0.62)\end{array}$ & $\begin{array}{l}12.61 \\
(0.43)\end{array}$ & & $\begin{array}{l}0.06 \\
(0.78)\end{array}$ & $\begin{array}{l}0.442 \\
(1.14)\end{array}$ & & $\begin{array}{l}1.82 \\
(0.78)\end{array}$ & $\begin{array}{l}14.82 * \\
(2.24)\end{array}$ & \\
\hline Founder Director & $\begin{array}{l}-3.811 \\
(-1.09)\end{array}$ & & $\begin{array}{l}-40.07^{* * *} \\
(-5.34)\end{array}$ & $\begin{array}{l}-0.08 \\
(-1.04)\end{array}$ & & $\begin{array}{l}-0.85 * * * \\
(-5.46)\end{array}$ & $\begin{array}{l}-1.87 \\
(-0.83)\end{array}$ & & $\begin{array}{l}-26.18^{* * *} \\
(-6.42)\end{array}$ \\
\hline \multicolumn{10}{|l|}{ SCHOOL CHARACTERISTICS } \\
\hline Log (Enrollment) & $\begin{array}{l}-0.740 \\
(-0.20)\end{array}$ & $\begin{array}{l}0.562 \\
(0.12)\end{array}$ & $\begin{array}{l}0.702 \\
(0.18)\end{array}$ & $\begin{array}{l}-0.0319 \\
(-0.38)\end{array}$ & $\begin{array}{l}0.0155 \\
(0.17)\end{array}$ & $\begin{array}{l}0.000280 \\
(0.00)\end{array}$ & $\begin{array}{l}-2.380 \\
(-1.06)\end{array}$ & $\begin{array}{l}-0.645 \\
(-0.25)\end{array}$ & $\begin{array}{l}-1.247 \\
(-0.48)\end{array}$ \\
\hline Log(School Age) & $\begin{array}{l}7.763 \\
(1.88)\end{array}$ & $\begin{array}{l}7.387 \\
(1.51)\end{array}$ & $\begin{array}{l}-1.035 \\
(-0.23)\end{array}$ & $\begin{array}{l}0.165 \\
(1.76)\end{array}$ & $\begin{array}{l}0.140 \\
(1.45) \\
-\end{array}$ & $\begin{array}{l}-0.0202 \\
(-0.20) \\
-\end{array}$ & $\begin{array}{l}5.130 \\
(1.72)\end{array}$ & $\begin{array}{l}4.098 \\
(1.46)\end{array}$ & $\begin{array}{l}-0.229 \\
(-0.07)\end{array}$ \\
\hline Government Funds / Total Assets & $\begin{array}{l}-0.0106 \\
(-1.85)\end{array}$ & $\begin{array}{l}-0.00944 \\
(-1.41)\end{array}$ & $\begin{array}{l}-0.00885 \\
(-1.59)\end{array}$ & $\begin{array}{l}-0.000290 * \\
(-2.19)\end{array}$ & $\begin{array}{l}0.000233 \\
(-1.70)\end{array}$ & $\begin{array}{l}0.000248^{*} \\
(-1.97)\end{array}$ & $\begin{array}{l}-0.00831 \\
(-1.98)\end{array}$ & $\begin{array}{l}-0.00636 \\
(-1.47)\end{array}$ & $\begin{array}{l}-0.00767 * \\
(-2.00)\end{array}$ \\
\hline Private Grants / Total Assets & $\begin{array}{l}-0.0660 * \\
(-2.49)\end{array}$ & $\begin{array}{l}-0.0830 \\
(-1.28)\end{array}$ & $\begin{array}{l}-0.0938^{* *} \\
(-2.78)\end{array}$ & $\begin{array}{l}-0.000898 \\
(-1.69)\end{array}$ & $\begin{array}{l}-0.00165 \\
(-1.45)\end{array}$ & $\begin{array}{l}-0.00160 * \\
(-2.26)\end{array}$ & $\begin{array}{l}-0.0108 \\
(-0.86)\end{array}$ & $\begin{array}{l}-0.0326 \\
(-1.55)\end{array}$ & $\begin{array}{l}-0.0295^{*} \\
(-2.25)\end{array}$ \\
\hline Elementary School & $\begin{array}{l}-8.869 * \\
(-2.12)\end{array}$ & $\begin{array}{l}-8.472 * \\
(-1.98)\end{array}$ & $\begin{array}{l}-8.202^{*} \\
(-2.24)\end{array}$ & $\begin{array}{l}-0.153 \\
(-1.67)\end{array}$ & $\begin{array}{l}-0.138 \\
(-1.53)\end{array}$ & $\begin{array}{l}-0.143 \\
(-1.75)\end{array}$ & $\begin{array}{l}-1.755 \\
(-0.67)\end{array}$ & $\begin{array}{l}-0.951 \\
(-0.36)\end{array}$ & $\begin{array}{l}-2.354 \\
(-1.05)\end{array}$ \\
\hline Middle School & $\begin{array}{l}4.103 \\
(0.63)\end{array}$ & $\begin{array}{l}3.113 \\
(0.52)\end{array}$ & $\begin{array}{l}4.968 \\
(0.88)\end{array}$ & $\begin{array}{l}0.0415 \\
(0.27)\end{array}$ & $\begin{array}{l}0.00944 \\
(0.07)\end{array}$ & $\begin{array}{l}0.0582 \\
(0.42)\end{array}$ & $\begin{array}{l}0.567 \\
(0.13)\end{array}$ & $\begin{array}{l}-0.165 \\
(-0.05)\end{array}$ & $\begin{array}{l}1.056 \\
(0.31)\end{array}$ \\
\hline High School & $\begin{array}{l}2.138 \\
(0.46)\end{array}$ & $\begin{array}{l}1.230 \\
(0.29)\end{array}$ & $\begin{array}{l}1.107 \\
(0.26)\end{array}$ & $\begin{array}{l}0.0260 \\
(0.25)\end{array}$ & $\begin{array}{l}0.00762 \\
(0.08)\end{array}$ & $\begin{array}{l}0.00517 \\
(0.05)\end{array}$ & $\begin{array}{l}0.238 \\
(0.08)\end{array}$ & $\begin{array}{l}-0.293 \\
(-0.11)\end{array}$ & $\begin{array}{l}-1.142 \\
(-0.44)\end{array}$ \\
\hline Percentage of Licensed Teachers & $\begin{array}{l}-0.126 \\
(-1.71)\end{array}$ & $\begin{array}{l}-0.131 \\
(-1.84)\end{array}$ & $\begin{array}{l}-0.134^{*} \\
(-2.24)\end{array}$ & $\begin{array}{l}-0.00298 \\
(-1.81)\end{array}$ & $\begin{array}{l}-0.00304 \\
(-1.92)\end{array}$ & $\begin{array}{l}-0.00331 * \\
(-2.53)\end{array}$ & $\begin{array}{l}-0.127^{*} \\
(-2.65)\end{array}$ & $\begin{array}{l}-0.129 * * \\
(-2.91)\end{array}$ & $\begin{array}{l}-0.140 * * * \\
(-3.56)\end{array}$ \\
\hline Percentage of Qualified Teachers & $\begin{array}{l}0.0736 \\
(0.85)\end{array}$ & $\begin{array}{l}0.0733 \\
(0.88)\end{array}$ & $\begin{array}{l}0.0203 \\
(0.29)\end{array}$ & $\begin{array}{l}0.00220 \\
(1.21)\end{array}$ & $\begin{array}{l}0.00199 \\
(1.14)\end{array}$ & $\begin{array}{l}0.00130 \\
(0.87)\end{array}$ & $\begin{array}{l}0.132 * * \\
(2.91)\end{array}$ & $\begin{array}{l}0.124^{* *} \\
(2.82)\end{array}$ & $\begin{array}{l}0.0852 * \\
(2.21)\end{array}$ \\
\hline Student-Teacher Ratio & $\begin{array}{l}-0.844 \\
(-1.16)\end{array}$ & $\begin{array}{l}-0.831 \\
(-1.19)\end{array}$ & $\begin{array}{l}-0.895 \\
(-1.33)\end{array}$ & $\begin{array}{l}-0.0144 \\
(-0.79)\end{array}$ & $\begin{array}{l}-0.0140 \\
(-0.86)\end{array}$ & $\begin{array}{l}-0.0142 \\
(-0.81)\end{array}$ & $\begin{array}{l}-0.397 \\
(-0.88)\end{array}$ & $\begin{array}{l}-0.400 \\
(-1.01)\end{array}$ & $\begin{array}{l}-0.450 \\
(-1.13)\end{array}$ \\
\hline
\end{tabular}




\begin{tabular}{|c|c|c|c|c|c|c|c|c|c|}
\hline \multirow{2}{*}{$\begin{array}{l}\text { Dependent Variable } \\
\text { Estimation Method: }\end{array}$} & \multicolumn{3}{|c|}{ Math Good Percentage } & \multicolumn{3}{|c|}{ Math Score Index } & \multicolumn{3}{|c|}{ CPI } \\
\hline & OLS & ATE & ATE & OLS & ATE & ATE & OLS & ATE & ATE \\
\hline \multirow[t]{2}{*}{$\%$ of Low Income Students } & $-0.49 * * *$ & $-0.49 * * *$ & $-0.43 * * *$ & $-0.012 * * *$ & $-0.012 * * *$ & $-0.010 * * *$ & $-0.34 * * *$ & $-0.34 * * *$ & $-0.299 * * *$ \\
\hline & $(-4.50)$ & $(-4.74)$ & $(-3.74)$ & $(-4.89)$ & $(-5.20)$ & $(-4.53)$ & $(-4.45)$ & $(-4.63)$ & $(-3.76)$ \\
\hline \multirow[t]{2}{*}{$\%$ of Black Students } & 0.0602 & 0.0447 & 0.0329 & 0.00148 & 0.00102 & 0.00109 & 0.0476 & 0.0326 & 0.0226 \\
\hline & $(0.59)$ & $(0.46)$ & $(0.35)$ & $(0.64)$ & $(0.49)$ & $(0.53)$ & $(0.69)$ & $(0.52)$ & $(0.35)$ \\
\hline \multirow[t]{2}{*}{$\%$ of Asian Students } & 0.0707 & 0.0331 & 0.0268 & 0.00321 & 0.00242 & 0.00244 & 0.0427 & 0.00688 & -0.00284 \\
\hline & $(0.31)$ & $(0.15)$ & $(0.14)$ & $(0.66)$ & $(0.53)$ & $(0.64)$ & $(0.29)$ & $(0.05)$ & $(-0.02)$ \\
\hline \multirow[t]{2}{*}{$\%$ of Hispanic Students } & 0.388 & 0.373 & $0.392 *$ & 0.00859 & 0.00832 & $0.00866^{*}$ & 0.217 & 0.190 & 0.191 \\
\hline & $(1.83)$ & $(1.89)$ & $(2.18)$ & $(1.79)$ & $(1.89)$ & $(2.16)$ & $(1.28)$ & $(1.19)$ & $(1.39)$ \\
\hline \multirow[t]{2}{*}{$\%$ of Native American Students } & 1.700 & 1.752 & 2.698 & 0.0346 & 0.0363 & 0.0588 & 1.438 & 1.354 & 1.699 \\
\hline & $(0.62)$ & $(0.68)$ & $(1.00)$ & $(0.60)$ & $(0.67)$ & $(0.99)$ & $(0.87)$ & $(0.88)$ & $(1.01)$ \\
\hline \multirow[t]{2}{*}{$\%$ of Non-native English Speakers } & 0.0896 & 0.0868 & 0.0934 & 0.00206 & 0.00199 & 0.00222 & 0.0966 & 0.114 & 0.0806 \\
\hline & $(0.60)$ & $(0.61)$ & $(0.83)$ & $(0.62)$ & $(0.64)$ & $(0.90)$ & $(0.70)$ & $(0.84)$ & $(0.78)$ \\
\hline \multirow[t]{2}{*}{ \% with Limited English Proficiency } & $-0.805^{* *}$ & $-0.813 * * *$ & $-0.89 * * *$ & $-0.017^{* * *}$ & $-0.017^{* * *}$ & $-0.018 * * *$ & $-0.542^{* *}$ & $-0.540 * *$ & $-0.520 * *$ \\
\hline & $(-3.40)$ & $(-3.47)$ & $(-3.82)$ & $(-3.46)$ & $(-3.52)$ & $(-3.94)$ & $(-2.98)$ & $(-3.09)$ & $(-3.09)$ \\
\hline \multirow[t]{2}{*}{$\%$ of Special Education } & -0.524 & $-0.529 *$ & $-0.609 *$ & -0.0117 & $-0.0122 *$ & $-0.0123 *$ & -0.429 & $-0.425^{*}$ & $-0.485^{*}$ \\
\hline & $(-1.91)$ & $(-1.99)$ & $(-2.41)$ & $(-1.87)$ & $(-2.01)$ & $(-2.11)$ & $(-1.99)$ & $(-2.21)$ & $(-2.52)$ \\
\hline \multirow[t]{2}{*}{$\%$ of Males } & -0.179 & -0.129 & -0.221 & -0.00533 & -0.00350 & -0.00638 & -0.190 & -0.159 & -0.206 \\
\hline & $(-0.74)$ & $(-0.49)$ & $(-1.00)$ & $(-0.98)$ & $(-0.60)$ & $(-1.33)$ & $(-1.00)$ & $(-0.85)$ & $(-1.16)$ \\
\hline \multirow[t]{2}{*}{ Constant } & $63.32 * *$ & 45.77 & $107.4^{* * *}$ & $2.938 * * *$ & $2.357^{* * *}$ & $3.836 * * *$ & $98.19 * * *$ & $91.11^{* * *}$ & $140.2^{* * *}$ \\
\hline & $(3.02)$ & $(1.04)$ & $(5.18)$ & $(6.66)$ & $(3.33)$ & $(8.73)$ & $(6.87)$ & $(5.00)$ & $(8.41)$ \\
\hline $\mathrm{N}$ & 427 & 427 & 427 & 427 & 427 & 427 & 355 & 355 & 355 \\
\hline Rho & $\mathrm{Na}$ & -0.33 & 0.88 & na & -0.53 & 0.86 & na & -0.61 & 0.92 \\
\hline Wald test of indep. Eqns.: Prob $>$ chi2 & $\mathrm{Na}$ & 0.7096 & 0.0000 & na & 0.2962 & 0.0000 & na & 0.0465 & 0.0000 \\
\hline Overall Fit of the Model: Prob > chi2 & 0.0000 & 0.0000 & 0.0000 & 0.0000 & 0.0000 & 0.0000 & 0.0000 & 0.0000 & 0.0000 \\
\hline
\end{tabular}

Notes: The table presents the results for the structural equation (Equation 2a in the text). All regressions are clustered at the charter school level and include year dummies.

*** Significant at the 0.001 level, ** Significant at the 0.01 level , * Significant at the 0.05 level 
Table 8. Multivariate Analyses of Academic Performance for Different Types of Financially Affiliated Directors

\begin{tabular}{|c|c|c|c|c|c|c|c|c|c|}
\hline \multirow{2}{*}{$\begin{array}{l}\text { Dependent Variable } \\
\text { BOARD MEMBERS }\end{array}$} & \multicolumn{3}{|c|}{ Math Good Percentage } & \multicolumn{3}{|c|}{ Math Score Index } & \multicolumn{3}{|c|}{ CPI } \\
\hline & & & & & & & & & \\
\hline \multirow{2}{*}{ Financial Affiliation with For-profit } & $36.22 * * *$ & & & $0.834 * * *$ & & & $20.52 * * *$ & & \\
\hline & $(5.15)$ & & & $(5.31)$ & & & $(5.30)$ & & \\
\hline \multirow[t]{2}{*}{ Financial Affiliation with Non-Profit } & & 10.79 & & & 0.380 & & & $12.53^{*}$ & \\
\hline & & $(0.49)$ & & & $(1.19)$ & & & $(2.29)$ & \\
\hline \multirow[t]{2}{*}{ Financially Affiliated and Founder } & & & $26.63 * *$ & & & $0.677^{* * *}$ & & & $18.12 * * *$ \\
\hline & & & $(2.67)$ & & & $(3.54)$ & & & $(3.48)$ \\
\hline \multicolumn{10}{|l|}{ SCHOOL CHARACTERISTICS } \\
\hline \multirow[t]{2}{*}{ Log (Enrollment) } & -2.520 & 1.122 & 2.000 & -0.0723 & 0.0326 & 0.0349 & -4.001 & -0.0209 & -0.602 \\
\hline & $(-0.64)$ & $(0.24)$ & $(0.47)$ & $(-0.85)$ & $(0.38)$ & $(0.36)$ & $(-1.67)$ & $(-0.01)$ & $(-0.23)$ \\
\hline \multirow[t]{2}{*}{ Log(School Age) } & $9.588 * *$ & 6.986 & $9.163^{*}$ & $0.202^{*}$ & 0.124 & 0.197 & $6.242 * *$ & 3.506 & 5.360 \\
\hline & $(2.62)$ & $(1.32)$ & $(2.04)$ & $(2.47)$ & $(1.20)$ & $(1.91)$ & $(2.64)$ & $(1.17)$ & $(1.77)$ \\
\hline \multirow[t]{2}{*}{ Government Funds / Total Assets } & -0.00746 & -0.00928 & -0.00816 & -0.000212 & -0.000233 & -0.000229 & -0.00663 & -0.00659 & -0.00722 \\
\hline & $(-1.39)$ & $(-1.59)$ & $(-1.47)$ & $(-1.75)$ & $(-1.85)$ & $(-1.79)$ & $(-1.73)$ & $(-1.69)$ & $(-1.83)$ \\
\hline \multirow[t]{2}{*}{ Private Grants / Total Assets } & $-0.0885^{* *}$ & -0.0809 & $-0.112 * *$ & $-0.00150 *$ & -0.00160 & $-0.00215^{*}$ & -0.0232 & -0.0312 & -0.0374 \\
\hline & $(-2.60)$ & $(-1.49)$ & $(-2.79)$ & $(-2.02)$ & $(-1.59)$ & $(-2.55)$ & $(-1.51)$ & $(-1.61)$ & $(-1.95)$ \\
\hline \multirow[t]{2}{*}{ Elementary School } & $-9.605 * *$ & $-8.942 *$ & $-9.654 *$ & $-0.166^{*}$ & -0.154 & $-0.176^{*}$ & -2.075 & -1.556 & -2.153 \\
\hline & $(-2.73)$ & $(-2.09)$ & $(-2.28)$ & $(-2.21)$ & $(-1.68)$ & $(-1.99)$ & $(-0.89)$ & $(-0.57)$ & $(-0.81)$ \\
\hline \multirow[t]{2}{*}{ Middle School } & 3.078 & 3.366 & 4.580 & 0.0121 & 0.0209 & 0.0616 & 0.236 & 0.254 & 0.857 \\
\hline & $(0.60)$ & $(0.58)$ & $(0.74)$ & $(0.10)$ & $(0.16)$ & $(0.42)$ & $(0.07)$ & $(0.07)$ & $(0.23)$ \\
\hline \multirow[t]{2}{*}{ High School } & 2.972 & 0.537 & 0.350 & 0.0415 & -0.00864 & -0.0104 & 0.793 & -0.922 & -1.364 \\
\hline & $(0.76)$ & $(0.13)$ & $(0.09)$ & $(0.49)$ & $(-0.09)$ & $(-0.12)$ & $(0.29)$ & $(-0.33)$ & $(-0.51)$ \\
\hline \multirow[t]{2}{*}{ Percentage of Licensed Teachers } & -0.0897 & -0.125 & -0.128 & -0.00209 & -0.00292 & -0.00280 & $-0.0986^{*}$ & $-0.123^{* *}$ & $-0.129 * *$ \\
\hline & $(-1.30)$ & $(-1.77)$ & $(-1.81)$ & $(-1.35)$ & $(-1.86)$ & $(-1.70)$ & $(-2.43)$ & $(-2.88)$ & $(-3.04)$ \\
\hline \multirow[t]{2}{*}{ Percentage of Qualified Teachers } & 0.0337 & 0.0836 & 0.0642 & 0.00135 & 0.00224 & 0.00182 & $0.106^{*}$ & $0.134^{* *}$ & $0.131 * *$ \\
\hline & $(0.41)$ & $(1.04)$ & $(0.78)$ & $(0.77)$ & $(1.28)$ & $(1.06)$ & $(2.52)$ & $(3.03)$ & $(3.05)$ \\
\hline \multirow[t]{2}{*}{ Student-Teacher Ratio } & -0.675 & -0.904 & -0.800 & -0.0105 & -0.0158 & -0.0131 & -0.201 & -0.434 & -0.328 \\
\hline & $(-1.04)$ & $(-1.30)$ & $(-1.13)$ & $(-0.68)$ & $(-0.98)$ & $(-0.78)$ & $(-0.45)$ & $(-1.07)$ & $(-0.72)$ \\
\hline
\end{tabular}




\begin{tabular}{|c|c|c|c|c|c|c|c|c|c|}
\hline \multirow{2}{*}{$\begin{array}{l}\text { Dependent Variable } \\
\% \text { of Low Income Students }\end{array}$} & \multicolumn{3}{|c|}{ Math Good Percentage } & \multicolumn{3}{|c|}{ Math Score Index } & \multicolumn{3}{|c|}{ CPI } \\
\hline & $\begin{array}{c}-0.49 * * * \\
(-4.33)\end{array}$ & $\begin{array}{c}-0.47^{* * *} \\
(-4.43)\end{array}$ & $\begin{array}{c}-0.48^{* * *} \\
(-4.66)\end{array}$ & $\begin{array}{c}-0.012 * * * \\
(-4.80)\end{array}$ & $\begin{array}{c}-0.011 * * * \\
(-4.94)\end{array}$ & $\begin{array}{c}-0.012^{* * *} \\
(-5.31)\end{array}$ & $\begin{array}{c}-0.34^{* * *} \\
(-4.47)\end{array}$ & $\begin{array}{c}-0.31 * * * \\
(-4.25)\end{array}$ & $\begin{array}{c}-0.33^{* * *} \\
(-4.70)\end{array}$ \\
\hline$\%$ of Black Students & $\begin{array}{c}0.0309 \\
(0.32)\end{array}$ & $\begin{array}{c}0.0361 \\
(0.38)\end{array}$ & $\begin{array}{c}0.0260 \\
(0.30)\end{array}$ & $\begin{array}{c}0.000873 \\
(0.41)\end{array}$ & $\begin{array}{c}0.000831 \\
(0.41)\end{array}$ & $\begin{array}{c}0.000737 \\
(0.39)\end{array}$ & $\begin{array}{l}0.0275 \\
(0.43)\end{array}$ & $\begin{array}{c}0.0225 \\
(0.37)\end{array}$ & $\begin{array}{c}0.0202 \\
(0.35)\end{array}$ \\
\hline$\%$ of Asian Students & $\begin{array}{l}0.0110 \\
(0.04)\end{array}$ & $\begin{array}{c}0.0374 \\
(0.17)\end{array}$ & $\begin{array}{l}-0.0154 \\
(-0.06)\end{array}$ & $\begin{array}{c}0.00151 \\
(0.31)\end{array}$ & $\begin{array}{c}0.00263 \\
(0.57)\end{array}$ & $\begin{array}{c}0.00139 \\
(0.26)\end{array}$ & $\begin{array}{l}-0.0169 \\
(-0.11)\end{array}$ & $\begin{array}{c}0.00332 \\
(0.02)\end{array}$ & $\begin{array}{l}-0.0441 \\
(-0.30)\end{array}$ \\
\hline$\%$ of Hispanic Students & $\begin{array}{l}0.367 \\
(1.82)\end{array}$ & $\begin{array}{l}0.338 \\
(1.72)\end{array}$ & $\begin{array}{l}0.344 \\
(1.72)\end{array}$ & $\begin{array}{c}0.00796 \\
(1.81)\end{array}$ & $\begin{array}{c}0.00755 \\
(1.73)\end{array}$ & $\begin{array}{c}0.00779 \\
(1.73)\end{array}$ & $\begin{array}{l}0.186 \\
(1.20)\end{array}$ & $\begin{array}{l}0.148 \\
(0.94)\end{array}$ & $\begin{array}{l}0.162 \\
(1.01)\end{array}$ \\
\hline$\%$ of Native American Students & $\begin{array}{l}0.125 \\
(0.95)\end{array}$ & $\begin{array}{l}0.103 \\
(0.71)\end{array}$ & $\begin{array}{c}0.0906 \\
(0.66)\end{array}$ & $\begin{array}{c}0.00282 \\
(0.98)\end{array}$ & $\begin{array}{c}0.00239 \\
(0.75)\end{array}$ & $\begin{array}{c}0.00208 \\
(0.70)\end{array}$ & $\begin{array}{l}0.138 \\
(1.17)\end{array}$ & $\begin{array}{l}0.145 \\
(1.07)\end{array}$ & $\begin{array}{l}0.120 \\
(0.95)\end{array}$ \\
\hline$\%$ of Non-native English Speakers & $\begin{array}{l}-0.77^{* *} \\
(-3.29)\end{array}$ & $\begin{array}{c}-0.82 * * * \\
(-3.51)\end{array}$ & $\begin{array}{c}-0.84^{* * *} \\
(-3.37)\end{array}$ & $\begin{array}{c}-0.016 * * * \\
(-3.32)\end{array}$ & $\begin{array}{c}-0.017^{* * *} \\
(-3.59)\end{array}$ & $\begin{array}{c}-0.018^{* * *} \\
(-3.50)\end{array}$ & $\begin{array}{l}-0.50 * * \\
(-3.15)\end{array}$ & $\begin{array}{l}-0.55^{* *} \\
(-3.26)\end{array}$ & $\begin{array}{c}-0.56 * * * \\
(-3.39)\end{array}$ \\
\hline \% with Limited English Proficiency & $\begin{array}{c}-0.507^{*} \\
(-2.15)\end{array}$ & $\begin{array}{l}-0.525^{*} \\
(-1.96)\end{array}$ & $\begin{array}{c}-0.542^{*} \\
(-2.20)\end{array}$ & $\begin{array}{c}-0.0111^{*} \\
(-2.12)\end{array}$ & $\begin{array}{c}-0.0120 \\
(-1.96)\end{array}$ & $\begin{array}{c}-0.0122 * \\
(-2.23)\end{array}$ & $\begin{array}{c}-0.412^{*} \\
(-1.97)\end{array}$ & $\begin{array}{c}-0.453^{*} \\
(-2.35)\end{array}$ & $\begin{array}{c}-0.451^{*} \\
(-2.22)\end{array}$ \\
\hline$\%$ of Special Education & $\begin{array}{l}0.192 \\
(0.20)\end{array}$ & $\begin{array}{l}0.121 \\
(0.11)\end{array}$ & $\begin{array}{l}0.182 \\
(0.17)\end{array}$ & $\begin{array}{c}0.00759 \\
(0.40)\end{array}$ & $\begin{array}{c}0.00572 \\
(0.26)\end{array}$ & $\begin{array}{c}0.00824 \\
(0.40)\end{array}$ & $\begin{array}{c}0.0624 \\
(0.11)\end{array}$ & $\begin{array}{c}-0.00521 \\
(-0.01)\end{array}$ & $\begin{array}{c}0.0453 \\
(0.07)\end{array}$ \\
\hline$\%$ of Males & $\begin{array}{c}-0.0733 \\
(-0.32)\end{array}$ & $\begin{array}{l}-0.144 \\
(-0.57)\end{array}$ & $\begin{array}{c}-0.0837 \\
(-0.34)\end{array}$ & $\begin{array}{c}-0.00277 \\
(-0.54)\end{array}$ & $\begin{array}{c}-0.00389 \\
(-0.68)\end{array}$ & $\begin{array}{c}-0.00271 \\
(-0.49)\end{array}$ & $\begin{array}{l}-0.145 \\
(-0.78)\end{array}$ & $\begin{array}{l}-0.180 \\
(-0.94)\end{array}$ & $\begin{array}{l}-0.162 \\
(-0.87)\end{array}$ \\
\hline Constant & $\begin{array}{l}57.88^{*} \\
(2.49)\end{array}$ & $\begin{array}{l}46.36 \\
(1.23) \\
\end{array}$ & $\begin{array}{l}33.89 \\
(1.23) \\
\end{array}$ & $\begin{array}{c}2.811^{* * *} \\
(5.62) \\
\end{array}$ & $\begin{array}{c}2.380 * * * \\
(3.76)\end{array}$ & $\begin{array}{c}2.200 * * * \\
(3.67)\end{array}$ & $\begin{array}{c}97.90 * * * \\
(6.04) \\
\end{array}$ & $\begin{array}{c}81.47^{* * *} \\
(5.07)\end{array}$ & $\begin{array}{c}82.81 * * * \\
(4.84)\end{array}$ \\
\hline $\mathrm{N}$ & 427 & 427 & 427 & 427 & 427 & 427 & 355 & 355 & 355 \\
\hline Rho & -0.71 & -0.36 & -0.64 & -0.76 & -0.54 & -0.72 & -0.63 & -0.63 & -0.65 \\
\hline Wald test of indep. Eqns.: Prob > chi2 & $0.0003 * * *$ & 0.5903 & $0.0254^{* *}$ & $0.0002 * * *$ & 0.1964 & $0.0022^{* *}$ & $0.0007 * * *$ & $0.0138^{*}$ & $0.0043^{* *}$ \\
\hline Overall Fit of the Model: Prob > chi2 & 0.0000 & 0.0000 & 0.0000 & 0.0000 & 0.0000 & 0.0000 & 0.0000 & 0.0000 & 0.0000 \\
\hline
\end{tabular}

Notes: The dependent variable is academic performance, measured from the math good percentage, math score index and CPI. All regressions are clustered at the charter school level and include year dummies. *** Significant at the 0.001 level, ** Significant at the 0.01 level,

* Significant at the 0.05 level 